\title{
Comprehensive analysis of bird mortality along power distribution lines in Slovakia
}

\author{
Komplexná analýza mortality vtákov na distribučných vedeniach na Slovensku
}

\author{
Marek GÁLIS, Ladislav NAĎO, Ervín HAPL, Ján ŠMÍDT, Lucia DEUTSCHOVÁ \& Jozef CHAVKO
}

\begin{abstract}
Collisions and electrocutions on power lines are known to kill large numbers of birds annually on a global scale. We conducted comprehensive research focused on bird mortality caused by $22 \mathrm{kV}$ and $110 \mathrm{kV}$ distribution power lines in 13 Special Protection Areas in Slovakia. In the period between December 2014 and February 2016, 6,235 km of power lines were inspected twice during two periods (12/2014-03/2015 and 04/2015-02/2016) of field survey. In addition an intensive study was conducted during the second field survey at one-month intervals on power lines identified as the most dangerous for birds to collide with. As a result, 4,353 bird carcasses and bird remains representing 84 bird species and 14 orders were identified. Electrocution was suspected for $76.72 \%$ and collision for $23.28 \%$ of fatalities. Raptors were associated with $40 \%$ of all identified victims of electrocution. Two peaks of incidence were recorded, the first in March with a high rate of electrocutions as well as collisions of swans, pheasants, common blackbirds, ducks and herons, and the second in September predominantly featuring electrocution of raptors, magpies and corvids. We were unable to quantify seasonal patterns of mortality due to the limited sample of repeated mortality surveys resulting from the large grid of inspected power lines. We conducted comprehensive statistical analysis of more than 100 configurations of pylons and calculated their potential risk towards birds. Strong spatial correlation was revealed in the data set. Metal branch pylons and corner pylons with exposed jumper wires passing over the supporting insulators above the cross arms were the most dangerous configuration, accounting for $34.72 \%$ of total recorded electrocution fatalities ( 0.13 carcass/pylon). Cases of electrocution were also recorded for two bird species of major conservation concern in Slovakia: saker falcon (Falco cherrug) and eastern imperial eagle (Aquila heliaca). The results of this study may substantially improve conservation management and policies needed to reduce bird mortality.
\end{abstract}

\begin{abstract}
Abstrakt: Nárazy vtákov a zásahy elektrickým prúdom zabíjajú v celosvetovom meradle každoročne vel'ké množstvo vtákov. Komplexný výskum, zameraný na mortalitu vtákov na 22 kV a 110 kV elektrických vedeniach, bol realizovaný v 13 chránených vtáčích územiach na Slovensku. V období od decembra 2014 do februára 2016, počas dvoch etáp (12/2014 - 03/2015 a 04/2015 - 02/2016) terénneho monitoringu, bolo dvakrát skontrolovaných $6235 \mathrm{~km}$ elektrických vedení. Okrem toho, prebiehal v mesačných intervaloch počas druhej etapy terénneho výskumu, intenzívny monitoring elektrických vedení, označených ako najrizikovejšie z pohl'adu možných nárazov. Identifikovali sme 4353 uhynutých jedincov, resp. zvyškov, zastúpených 84 druhmi vtákov zo 14 radov. Zásahy prúdom boli zodpovedné za 76,72 \% úmrtí, nárazy za 23,28 \% úmrtí. Dravce tvorili až 40 \% všetkých identifikovaných obetí v dôsledku zásahu prúdom. Zaznamenali sa dva sezónne vrcholy výskytu úhynov, vždy v období migrácií. Prvý v marci, s vysokým počtom úhynov v dôsledku zásahov, ale aj nárazov, najmä u labutí, bažantov, drozdov, kačíc a volaviek. Druhý vrchol pripadal na september, spojený s úmrtiami v dôsledku zásahov u dravcov a krkavcovitých druhov. Kvôli obmedzenej vzorke opakovaných prieskumov mortality vyplývajúcich z vel'kého rozsahu monitorovaných elektrických vedení, sme nedokázali kvantifikovat' sezónne vzorce úmrtnosti. Vykonali sme komplexnú štatistickú analýzu viac ako 100 konfigurácií stožiarov a vypočítali sme ich potenciálne riziko pre vtáky. V súbore údajov bola odhalená silná priestorová korelácia. Najnebezpečnejšiu konfiguráciu z hl'adiska zásahov prúdom, predstavovali tzv. odbočné ocel'ové stožiare s neizolovanými preponkami a rohové stĺpy s preponkami vedenými ponad konzolu, zodpovedné za 34,72 \% všetkých určených úmrtí ( 0,13 úhynov/stĺp). Zaznamenané boli aj prípady úhynov $\mathrm{v}$ dôsledku zásahov prúdom u dvoch druhov vtákov, ktoré sú na Slovensku významné z hl'adiska ich ochrany: sokola rároha (Falco cherrug) a orla král'ovského (Aquila heliaca). Výsledky tejto štúdie môžu významne zlepšit’ manažment ochrany a postupov potrebných na zníženie úmrtnosti vtákov.
\end{abstract}

Key words: electrocution, collisions, raptors, waterbirds, mitigation measures

Marek Gális*, Ervín Hapl, Ján Šmídt, Lucia Deutschová, Jozef Chavko, Raptor Protection of Slovakia, Trhová 54, SK-841 01 Bratislava 42, Slovakia.*E-mail: galis@dravce.sk.

Ladislav Nad'o, Institute of Forest Ecology, Slovak Academy of Sciences, Ludovíta Štúra 2, SK-960 01 Zvolen, Slovakia. 
Gális M, Nad’o L, Hapl E, Šmídt J, Deutschová L \& Chavko J: Comprehensive analysis of bird mortality along power distribution lines in Slovakia

Acknowledgments: These results were obtained and analyzed within the project LIFE13 NAT/SK/001272 Energy in the land power lines and conservation of priority bird species at Natura 2000 sites (www.lifeenergia.sk), supported by the European Commission under the LIFE programme and the Ministry of Environment of the Slovak Republic. We especially thank all the field assistants who carried out the field survey, namely: J. Achberger, G. Augustiničová, K. Bacsa, G. Benčuríková, T. Blaškovič, M. Boroš, J. Brndiar, A. Bukovič, P. Cibula, D. Csepányiová, A. Dočolomanský, V. Drahovský, M. Gajdoš, A. Gajdošová, S. Grambličková, E. Gulák, M. Harčár, Š. Horváth, A. I. Hučok, A. Izakovič, I. Jakab, A. Jakubcová, M. Jarošíková, M. Kaliský, D. Kerestúr, J. Kicko, K. Kicková, J. Klein, J. Klešík, O. Kmet', P. Kňazovič, L. Kňazovičová, A. Kostrová, P. Laboš, J. Lengyel, D. Lőbbová, L. Majdanová, P. Miškarík, M. Mojžǐ̌s, P. Petluš, V. Petlušová, J. Ratičák, Z. Riflik, A. Sekula, S. Senk, M. Szabo, M. Šara, K. Šotnár, A. Tonhaiserová, M. Trnka, F. Tulis, V. Tvrdíková, R. Uhrinová, A. Vereš, T. Veselovský, P. Vrlík \& M. Zemko. We wish to thank anonymous reviewers and the managing editor for the valuable comments on the text.

\section{Introduction}

Depending on the type of construction, power lines may cause fatal injuries and death to birds due to electrocution and collision. Electrocution is a worldwide problem identified especially on mediumvoltage types of power line $(1-52 \mathrm{kV})$. It has been documented in a number of earlier and more recent reports from the USA (APLIC 2006, Lehman et al. 2010, Dwyer et al. 2015). The problem has also been described in various countries in Asia, e.g. Mongolia, Saudi Arabia, India, Dagestan (Gombobaatar et al. 2004, Harness et al. 2008, Karyakin et al. 2009, Shobrak 2012, Harness et al. 2013, Gadziev 2013) and in Europe (Ferrer et al. 1991; Janss \& Ferrer 2001, Haas et al. 2005, Demerdziev et al. 2009, Samushenko et al. 2012, Demerdziev 2014, Demeter et al. 2018). Several of the available studies include quantified avian electrocution rates. The highest risk is associated primarily with medium-voltage power lines representing very attractive perches to many birds in open rural areas without tree growth (APLIC 2006). The group most threatened with electrocution are defined as the diurnal bird species, specifically eagles, hawks, vultures, kites, falcons, owls, storks and corvids (Haas et al. 2005, Guil et al. 2011, Prinsen et al. 2011, Ferrer 2012, Gadziev 2013, Fransson et al. 2019, Škorpíková et al. 2019). The highest mortality rate due to electrocution is registered mainly for medium-sized and large birds. In certain cases it can have significant negative effect on the species, either on the local scale or even at the population level, such as has been documented for the saker falcon (Harness et al. 2008, Kovács et al. 2014) or imperial eagle (Bagyura et al. 2002, Karyakin et al. 2009, Demeter et al. 2018).

Collisions of birds with electrical lines represent a significant mortality factor for several species. They have been noted as an important cause of mortality and they vary with habitat, local avian populations, line design (Ward \& Anderson 1992, Koops 1994, Roig \& Navazo 1997, Hunting 2002, Bevanger \& Brøseth 2004, Wright et al. 2008, APLIC 2012, Shobrak 2012, Sporer et al. 2013) and line orientation (Brown 1993). Power lines crossing the birds' daily movement corridors can be particularly problematic (Bevanger \& Brøseth 2004, Frost 2008, Stehn \& Wassenich 2008). There are great differences between habitats: on grassland there are 113 collisions $/ \mathrm{km} /$ year; on agricultural land 58 collisions $/ \mathrm{km} /$ year, and near river crossings 489 collisions $/ \mathrm{km} /$ year (Erikson et al. 2005). Collision risks also are exacerbated during low light, fog, or inclement weather conditions (Savereno et al. 1996, APLIC 2012).

Bird casualties due to collision with above-ground power lines can happen on any electricity grids (distribution or transmission) (Bahat 2008, Jenkins et al. 2010). Larger, heavy-bodied birds with short wing spans and poorer vision (Kelly \& Kelly 2009) are more susceptible to collisions than smaller, light-weight birds with relatively large wing spans, agility and good vision (Bevanger 1998, Shaw et al. 2010, APLIC 2012). Understanding the nature of bird collisions is essential for minimizing them. Problems of collisions with power lines can be divided into four main categories generally based on factors of origin, namely from the biological, topographical, meteorological and technical perspective (APLIC 2012).

Electrocution and collisions are still an important, continuing mortality factor for several bird species, despite the number of mitigation measures implemented worldwide. They represent a biologically significant risk, since for species which are rare or endangered, the loss of a few or even one individual may impact a local population or the overall population's viability (Crowder 2000).

In Slovakia the problem of electrocution has been the focus for mitigation measures since 1991. The first insulation device was designed by the NGO named 
SVODAS (since 2004 Raptor Protection of Slovakia) in cooperation with the State Nature Conservancy of the Slovak Republic, in the form of plastic combs preventing birds from perching on poles, and was installed in 1993 in Mala Fatra mountains. Since then many other solutions have been designed and tested. Deaths from collisions were identified sporadically by local experts, rescue stations or in field surveys carried out under small projects until 2009. The first field research focusing exclusively on collision mortality was held in 2010 in Ondavská rovina Special Protection Area (hereafter SPA). The results proved the need for a systematic approach and further study of the topic. Especially for this reason, the LIFE Energy project was designed and started being implemented in 2014.

In this study we present the results of field monitoring of bird mortality on $22 \mathrm{kV}$ and $110 \mathrm{kV}$ lines in 13 Special Protection Areas (SPAs) and their adjacent areas in Slovakia. The main objectives were to analyse the risk of distribution power lines for different bird species and compare electrocution and collision mortality rates on different pole types/designs, power line constructions, and then to propose protection measures against electrocution. It was the largest scope of systematic survey and evaluation conducted on this topic so far in Slovakia. In our study we also aimed to investigate which bird species were affected by collisions and electrocutions, how different pole designs could influence the rate of electrocution mortality, which bird protection measures were effective, and whether power line design could influence the risk of possible collision. Preliminary results from our findings have been published in studies by Gális et al. (2016, 2017a, 2017b, 2018a, 2018b \& 2019).

\section{Material and methods}

\section{S t u d y a r e a}

The field survey was carried out in 13 SPAs and their adjacent areas: Záhorské Pomoravie, Dunajské Luhy, Lehnice, Král'ová, Ostrovné lúky, Dolné Považie, Parížske močiare, Poiplie, Slovenský kras, Košická kotlina, Ondavská rovina, Medzibodrožie, Senianske rybníky, taking in an area of approximately $8,685 \mathrm{~km}^{2}$, including 2,250 $\mathrm{km}^{2}$ within SPAs. All SPAs are located in the southern part of Slovakia (Fig. 1), mainly in lowland agricultural landscapes (except for the Slovenský kras karst area). The selected surveyed area is of high avifaunic importance for birds using the area for breeding, roosting, during migration and/or foraging habitats (Karaska et al. 2015). Intensive agricultural use has led to a decrease in tree growth resulting in increasing preference of birds of prey for electricity pylons (APLIC 2006), especially in rural areas.

A considerable part of the national population of imperial eagle ( $60 \%$ of all pairs) and saker falcon $(80 \%$ of all pairs) together with many other raptors, water and

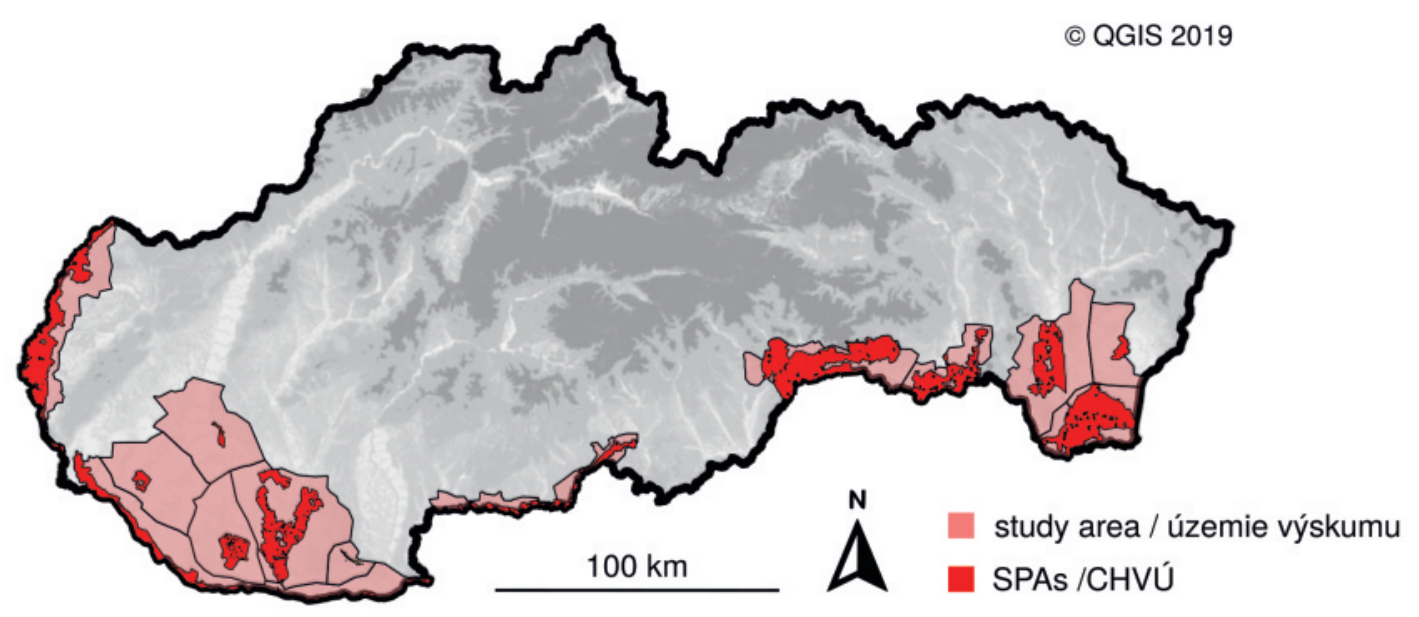

Fig. 1. Location of study area covering 13 Special Protection areas (SPA) and their adjacent areas.

Obr. 1. Poloha skúmaného územia, zahŕňajúceho 13 Chránených vtáčích území (CHVÚ) a ich prilahlé okolie. 
Gális M, Nad’o L, Hapl E, Šmídt J, Deutschová L \& Chavko J: Comprehensive analysis of bird mortality along power

distribution lines in Slovakia

wetland species are concentrated within this area. The project area is also an important human settlement area, which has led to electrification with the potential for causing significant bird mortality. The occurrence of many wetlands, marshes, rivers, lakes and ponds separated by these power lines represents great exposure to collision, especially for wetland bird species.

P ow e r l i n e characteristics

Electric power is delivered within Slovakia via two main groups of power supply operators. One national transmission company, the Slovak electricity transmission system (SEPS) operates a grid of app. 2,300 km of high and extra-high voltage lines $(220 \mathrm{kV}$ and $400 \mathrm{kV})$. Three regional $22 \mathrm{kV}$ and $110 \mathrm{kV}$ distribution service providers (Západoslovenská distribučná, a. s., Stredoslovenská distribučná, a. s. and Východoslovenská distribučná, a. s.) operate $30,970 \mathrm{~km}$ of medium and high-voltage lines. Two types of distribution power lines with a total length of $6,235 \mathrm{~km}$ cross the project area; a single/double circuit $22 \mathrm{kV}$ line and single/ double circuit $110 \mathrm{kV}$ line (with one earth wire above the phase conductors).

M o r t a lity s u r v e y s

Two periods of field survey were carried out between the years 2014 and 2016). During the first field study period (12/2014-03/2015) $6,235 \mathrm{~km}$ of $22 \mathrm{kV}(5,211$ $\mathrm{km})$ and $110 \mathrm{kV}(1,024 \mathrm{~km})$ power lines were surveyed once in the project area for bird carcasses and for technical data about pole and pylon construction. The data collected in this period were used to assess mortality rates comparing different species and poles construction. The buffer for the survey was defined as a distance of $10 \mathrm{~m}$ from the edge conductor in the case of $22 \mathrm{kV}$ and $25 \mathrm{~m}$ in the case of $110 \mathrm{kV}$ lines. The survey was conducted by one trained field assistant for $22 \mathrm{kV}$ and two assistants for $110 \mathrm{kV}$ walking in parallel with the electricity line. Walking in zig-zag pattern was carried out only in high and dense vegetation or crops. The slow, regular pace used during the survey optimized the results and decreased the searcher bias. Trained field assistants were also paid for each carcass found, to be motivated to survey the area properly.

The location of each bird carcasses or remains found was recorded by GPS device and described with eight parameters [identification by species or in the most precise taxonomic category possible, sex and age (if possible), cause of death (electrocution, collision, other or unknown cause of death), distance and direction to the pole and conductors, description of visible injury, stage of carcass decomposition, effect of scavengers]. Data were accompanied by a photo of the whole carcass, injuries and location with regard to the closest pole/ pylon. For bird collision victims, the location and distance from the wires were recorded to identify the possible effect of power line orientation on collision mortality. For each electricity pole and pylon, special technical data were collected together with other abiotic and biotic factors about the surrounding land use, landscape structure and habitat important for birds. The information recorded for every single pole included: GPS coordinates, type (position in the line), number of circuits, material of pole/pylon (concrete, metal or wood), number of poles, number of vertical separation of wires, number of cross arms, type of cross-arm, number of insulators per conductor, position of insulators, presence and type of insulators and their current quality state (O.K., damaged or wrong application). The presence and position of jumpers were also noticed. All poles/ pylons were photographed for verification of the data collected in the field. All detected bird carcasses were removed from the area during the first period of field survey to prevent double counts in the second (detailed) survey. All gathered data were processed and used as inputs for special collision-risk methodology (Šmídt et al. 2019) to select the power lines for intensive survey within the second field period.

In the second field period (04/2015-02/2016) a survey was conducted once on the same length of power lines investigated in first period $(6,235 \mathrm{~km})$. In addition, intensive surveys were conducted at one-month intervals on power lines identified as the most dangerous for birds to collide with, based on the results from the first period of field survey and collision-risk methodology. During these surveys, an area with a buffer zone of $20 \mathrm{~m}$ + the base of each pole (for $22 \mathrm{kV}$ ) and $50 \mathrm{~m}$ (for 110 $\mathrm{kV}$ ) from the edge of the power lines was surveyed for bird carcasses. All identified bird carcasses were removed from the area to prevent double counts. All birds found within a radius of $3 \mathrm{~m}$ from the poles with or without evidence of burn marks on feathers, feet or bill were considered as electrocuted. Birds found under or close to the phase conductors were considered to be victims of collisions. The body condition of bird carcasses was also taken into account, to estimate the possible date of death.

Altogether 81 field assistants were trained by ornithologists and GIS experts during two theoretical and practical training sessions, and several field meet- 
ings were held to ensure proper survey data collection together for both reporting periods. The experts (in the role of supervisors) joined the field assistants during the initial field surveys to decrease searcher bias and ensure proper data collection and transcription. A survey monitoring protocol was designed and used. If relevant, nearby tree and shrub growth was inspected up to $100 \mathrm{~m}$ from the border of the surveyed buffer zone, because injured birds often move themselves or are moved by predators. All gathered data were verified, revised by experts in ornithology and recorded in an offline database. Additionally, the size category of the species: small (wingspan 20-50 cm), medium (51-120), large $121-230 \mathrm{~cm}$ ) was identified, and it was assigned to one of the orders (waders, anglers, birds of prey/owls, pigeons, ravens, ducks/geese/swans, short-winged birds, cuckoos/swifts, songbirds and mercenaries). Monitoring was carried out only in suitable weather and site conditions, to avoid searcher bias in some crops or in unfavourable weather. The majority of the field visits was concentrated in the period when most crops were already harvested and the vegetation in the open landscape was low (the field survey was stopped if the vegetation was higher than the ankle, to reduce observer error mainly regarding small birds). Only records of carcasses showing confirmed interaction with a power line (death or injury) were selected for post-processing and subsequent statistical analyses. Individuals in an advanced stage of decomposition were excluded from further data analysis (it was not possible to determine the cause of death). Data from this survey were used to calculate the relative mortality rate for electrocution and collision, the effects of different types of pole construction, and the efficacy of already-installed protective measures against electrocution.

\section{$\mathrm{D}$ a $\mathrm{t}$ a a n a $1 \mathrm{ys}$ is}

The main objective of the statistical analysis was to determine the risk of individual types of electricity poles and pylons to birds, namely: (i) the risk of electrocution caused by direct contact; and (ii) the risk of collision. The parameters of the power line are given by the poles or pylons holding the wires along it. For the purposes of evaluation, therefore, each record of interaction was assigned to a particular pole or pylon, both in the case of electrocution as well as collision. The dataset analysed consisted of 64,649 utility poles and pylons $(60,925$ of $22 \mathrm{kV}$ and 3,724 of $110 \mathrm{kV})$, under 3,156 of which at least one dead bird was recorded. In total, 4,363 animal carcasses were found during the first and second field study periods together, almost all of which ( $>99 \%$ of cases) were birds. $110 \mathrm{kV}$ lines killed birds exclusively by collision (carcasses assigned to 186 pylons). For each type of pole/pylon a mean risk value was calculated using Blaker's exact confidence intervals (95\%) for binomial distribution (Blaker 2000). These confidence intervals are symmetrical around the mean value and provide information on mean variability, which in our case allowed us to identify statistically significant differences in risk between different types of poles and pylons. The calculation could only be carried out under the condition: (i) that at least one record of incident was assigned to the specific type of pole/pylon; (ii) the sample size was above 10 poles/pylons in the dataset. Blaker's confidence intervals were then visualized using barplots, where the top of the bar corresponds to the mean risk value and the vertical line represents the $95 \%$ confidence interval for that mean value. By comparing the overlap of confidence intervals, statistically significant differences in risk rates can be determined. Subsequently we used the sorting algorithm "k-means", which divided the utility poles into five groups according to the level of risk for birds (low, $\mathrm{p}_{\text {kill }}$ $=0.04 \pm 0.02$; low-medium, $p_{\text {kill }}=0.12 \pm 0.03$; medium, $\mathrm{p}_{\text {kill }}=0.21 \pm 0.03$; medium-high, $\mathrm{p}_{\text {kill }}=0.37 \pm 0.05$; high, $\mathrm{p}_{\mathrm{kill}}=0.57 \pm 0.09$ ). The same approach (but without the use of "k-means") was followed in further analyses taking into account the differences in risk for birds with regard to the type of pole, presence of jumper wire, size and ecological group of the killed bird and type of protection). All statistical calculations were performed in the R language 3.6.1 environment (R Core Team 2019) using the "MASS" (Venables \& Ripley 2002) and "PropCIs" libraries version 0.3-0 (Scherer 2018). In the second part of the statistical evaluation, the aim was to allocate zones with a high incidence of bird mortality due to electrocution for individual geographical areas (so-called "death zones"). For this purpose, we applied 2D-Kernel density estimation to the geographic coordinates of the recorded mortality incidents, and then projected the results onto a map ("kernels for individual areas").

\section{Results}

In total 4,353 victims were identified under all surveyed power lines. For 3,900 individuals belonging to 84 species it was possible to determine the cause of death (Tab. 1). Descriptive analysis showed that $22 \mathrm{kV}$ lines killed birds in both ways, i.e. by electrocution (2,096 poles) and by collision (588 poles/pylons, whereby electrocu- 
Gális M, Nad’o L, Hapl E, Šmídt J, Deutschová L \& Chavko J: Comprehensive analysis of bird mortality along power distribution lines in Slovakia

Tab. 1. Distribution of identified carcasses by taxa (12/2014-02/2016).

Tab. 1. Rozdelenie identifikovaných kadáverov podla taxónov (12/2014-02/2016).

\begin{tabular}{|c|c|c|c|c|c|c|c|}
\hline species / druh & $\begin{array}{l}\text { electrocution I } \\
\text { zásah prúdom }\end{array}$ & $\begin{array}{l}\text { collision I } \\
\text { náraz }\end{array}$ & $\Sigma$ & species / druh & $\begin{array}{l}\text { electrocution I } \\
\text { zásah prúdom }\end{array}$ & $\begin{array}{l}\text { collision I } \\
\text { náraz }\end{array}$ & $\Sigma$ \\
\hline Accipiter gentilis & 29 & - & 29 & Erithacus rubecula & - & 4 & 4 \\
\hline Accipiter nisus & 11 & 2 & 13 & Falco cherrug & 7 & - & 7 \\
\hline Acrocephalus scirpaceus & - & 1 & 1 & Falco tinnunculus & 95 & 3 & 98 \\
\hline Alauda arvensis & - & 8 & 8 & Falco sp. & 10 & - & 10 \\
\hline Anas crecca & 1 & 3 & 4 & Ficedula hypoleuca & - & 1 & 1 \\
\hline Anas platyrhynchos & - & 47 & 47 & Fringilla coelebs & - & 3 & 3 \\
\hline Anas sp. & 2 & 11 & 13 & Fulica atra & - & 2 & 2 \\
\hline Anser anser & - & 2 & 2 & Gallinago gallinago & - & 1 & 1 \\
\hline Anser sp. & - & 2 & 2 & Gallinula chloropus & - & 2 & 2 \\
\hline Aquila heliaca & 6 & - & 6 & Garrulus glandarius & 6 & 2 & 8 \\
\hline Aquila pomarina & 1 & - & 1 & Grus grus & - & 3 & 3 \\
\hline Aquila sp. & 1 & - & 1 & Ixobrychus minutus & - & 1 & 1 \\
\hline Ardea cinerea & - & 14 & 14 & Lanius collurio & - & 1 & 1 \\
\hline Ardea purpurea & - & 2 & 2 & Larus cachinnans & - & 2 & 2 \\
\hline Ardea sp. & - & 1 & 1 & Chroicocephalus ridibundus & - & 3 & 3 \\
\hline Asio flammeus & - & 1 & 1 & Larus sp. & - & 11 & 11 \\
\hline Asio otus & 24 & 11 & 35 & Locustella sp. & - & 1 & 1 \\
\hline Aves & 145 & 40 & 185 & Motacilla alba & - & 1 & 1 \\
\hline Aythya ferina & - & 1 & 1 & Muscicapa striata & - & 1 & 1 \\
\hline Bubo bubo & 5 & - & 5 & Oenanthe oenanthe & - & 1 & 1 \\
\hline Buteo buteo & 1025 & 3 & 1028 & Pandion haliaetus & 1 & - & 1 \\
\hline Buteo rufinus & 1 & - & 1 & Parus major & 4 & 4 & 8 \\
\hline Carduelis carduelis & - & 3 & 3 & Passer domesticus & 1 & - & 1 \\
\hline Carduelis chloris & - & 3 & 3 & Passer montanus & 2 & 7 & 9 \\
\hline Ciconia ciconia & 80 & 12 & 92 & Passer sp. & 34 & 25 & 59 \\
\hline Ciconia nigra & 2 & - & 2 & Phalacrocorax carbo & - & 2 & 2 \\
\hline Circus aeruginosus & 1 & 1 & 2 & Phasianus colchicus & - & 120 & 120 \\
\hline Circus cyaneus & - & 1 & 1 & Phylloscopus collybita & - & 1 & 1 \\
\hline Circus sp. & - & 1 & 1 & Pica pica & 601 & 5 & 606 \\
\hline Cocc. coccothraustes & - & 5 & 5 & Porzana parva & - & 2 & 2 \\
\hline Columba livia & 34 & 27 & 61 & Rallus aquaticus & - & 3 & 3 \\
\hline Columba oenas & 1 & 1 & 2 & Regulus regulus & - & 1 & 1 \\
\hline Columba palumbus & 15 & 2 & 17 & Saxicola rubetra & - & 1 & 1 \\
\hline Columba sp. & 61 & 70 & 131 & Streptopelia decaocto & 20 & 7 & 27 \\
\hline Corvus corax & 102 & 3 & 105 & Streptopelia turtur & - & 2 & 2 \\
\hline Corvus cornix & 212 & 6 & 218 & Strix aluco & 13 & - & 13 \\
\hline Corvus frugilegus & 129 & 3 & 132 & Sturnus vulgaris & 20 & 14 & 34 \\
\hline Corvus monedula & 22 & - & 22 & Sylvia atricapilla & - & 9 & 9 \\
\hline Corvus sp. & 253 & 5 & 258 & Sylvia borin & - & 2 & 2 \\
\hline Coturnix coturnix & - & 6 & 6 & Sylvia communis & - & 2 & 2 \\
\hline Crex crex & - & 4 & 4 & Sylvia curruca & - & 3 & 3 \\
\hline Cuculus canorus & 1 & 2 & 3 & Turdus iliacus & - & 2 & 2 \\
\hline Cygnus olor & - & 189 & 189 & Turdus merula & 2 & 58 & 60 \\
\hline Delichon urbicum & - & 2 & 2 & Turdus philomelos & 1 & 32 & 33 \\
\hline Dendrocopos major & - & 1 & 1 & Turdus pilaris & 2 & 30 & 32 \\
\hline Dendrcopos sp. & 1 & 1 & 2 & Turdus viscivorus & - & 2 & 2 \\
\hline Ardea alba & - & 10 & 10 & Turdus sp. & 7 & 5 & 12 \\
\hline Emberiza citrinella & - & 6 & 6 & Tyto alba & 1 & - & 1 \\
\hline Emberiza schoeniclus & - & 4 & 4 & Vanellus vanellus & - & 9 & 9 \\
\hline
\end{tabular}

tion was much more common $\left(\chi^{2}=847.24, \mathrm{df}=1, \mathrm{P}<\right.$ $0.001)$. $110 \mathrm{kV}$ lines killed birds exclusively by collision (carcasses assigned to 186 pylons). The majority (76.72\% 2,992 ind.) was killed by electrocution, and
$23.28 \%$ (908 ind.) solely due collision with wires. In the case of 451 carcasses it was not possible to determine the cause of death due to their advanced stage of decomposition. Two instances of beech marten (Martes foina) 
Fig. 2. Seasonal distribution of bird mortality due to electrocution and collision during both survey periods.

Obr. 2. Sezónna dynamika úhynov vtákov $\mathrm{s}$ rozlíšením podla príčiny úmrtia za obe etapy monitoring.

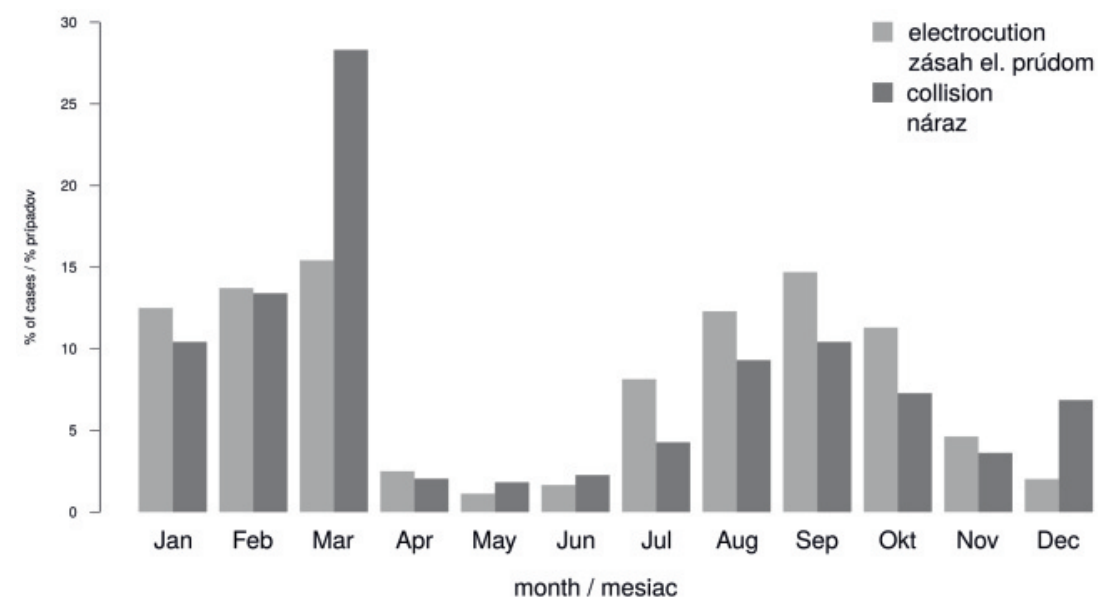

a single pole varied from 1 to 24 (recorded under a metal branch pole).

The common buzzard (Buteo buteo) was the most common bird of prey detected and was associated with $85.39 \%$ ( 1,023 ind.) of all identified electrocution of raptors $(\mathrm{n}=1,198)$, in $34.19 \%$ of all electrocutions and in $26.23 \%$ of all recorded bird carcasses (electrocution + collision). Second highest mortality was observed for the Eurasian magpie (Pica pica) with 20.08\% (601 ind.) and third for the hooded crow (Corvus cornix) with $7.08 \%$ (212 ind.).

During the field survey (12/2014-2/2016) six carcasses of imperial eagle and eight of saker falcon were identified under $22 \mathrm{kV}$ poles as a result of electrocution. In our study we also use the reported data from the period after the field survey (3/2016-9/2019) but only if

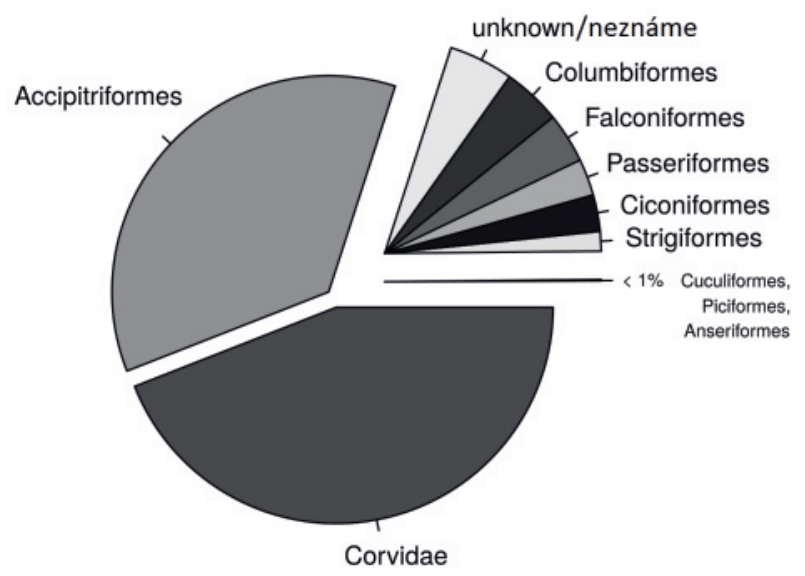

Fig. 3. Identified electrocutions in different taxonomic groups. Obr. 3. Podiel úmrtnosti $v$ dôsledku zásahov prúdom pre jednotlivé taxóny. the family Corvidae are listed separately from the ot Passeriformes. The number of carcasses found under 
Gális M, Nad’o L, Hapl E, Šmídt J, Deutschová L \& Chavko J: Comprehensive analysis of bird mortality along power distribution lines in Slovakia

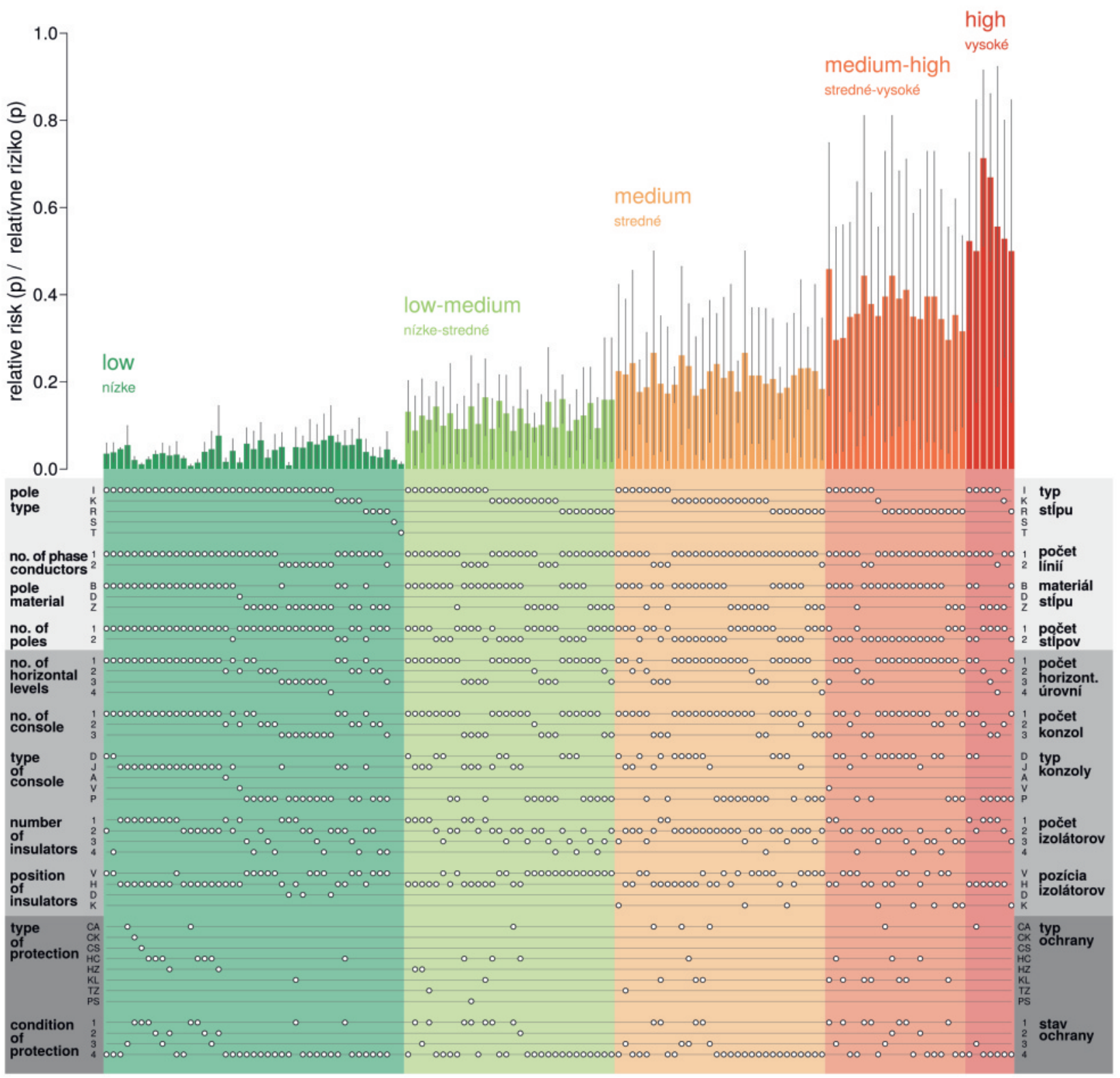

Fig. 4. Risk of individual types of utility poles $(22 \mathrm{kV})$ to birds. Bar height represents the relative risk of electrocution of various types of utility poles. Vertical lines at each bar represents Blaker's exact confidence intervals (95\%) for risk level. White points below bars on the horizontal axis represent presence/absence of individual pole components (white point/no point). Abbreviations: Pole type: I utility pole in straight line, $\mathrm{K}$ - corner pole, $\mathrm{R}$ - angle pole, $\mathrm{S}$ - switcher, $\mathrm{T}$ - pole transformer; Pole material: $\mathrm{B}$ - concrete, D - wood, $\mathrm{Z}$ - steel; Type of console: $\mathrm{D}$ - double metal console $\mathrm{J}$ - metal console, A - antibird console, V - old wood console, P - heavy metal console; Position of insulators: $\mathrm{V}$ - horizontal, $\mathrm{H}$ - upright, $\mathrm{D}$ - hanging, $\mathrm{K}$ - combined; Type of protection: CA - console protection , $\mathrm{CK}$ - console insulation, CS - console insulation, $\mathrm{HC}$ - back plastic combs, $\mathrm{HZ}$ - green plastic combs, $\mathrm{KL}$ - plastic cover, TZ - plastic triangle, Condition of protection: 1 - OK, 2 - damaged, 3 - wrong application, 4 - no protection.

Obr. 4. Rizikovost' jednotlivých typov stípov (22 kV) pre vtáky. Výška stĺpcov vyjadruje priemernú hodnotu rizika zásahu prúdom. Vertikálne čiary prechádzajúce stredom každého stípca vyjadrujú Blakerove $95 \%$-tné intervaly spol'ahlivosti pre priemernú hodnotu rizika. Biele body pod jednotlivými stĺpcami symbolizujú prítomnost'/neprítomnost' jednotlivých konštrukčných komponentov stípu (biely bod/žiadny bod). Skratky: Typ stípu: I - stíp na priamej línií, K - odbočný stíp, R - rohový stĺp, S - úsekový odpínač, T transformátor. Materiál stípu: B - betón, D - drevo Z - ocel'; Typ konzoly: D - dvojitá, J - lahká rovinná, A - antibird/ecobird, V - 

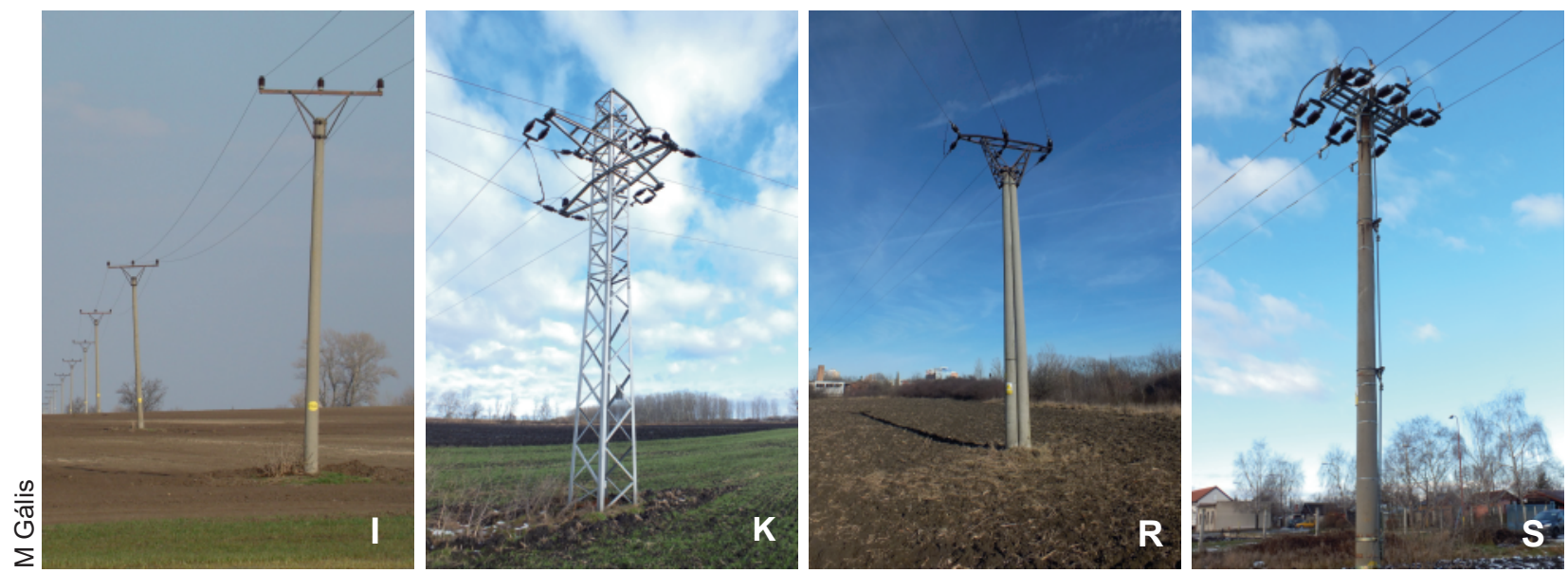

Fig. 5. Basic categorization of $22 \mathrm{kV}$ pole configurations in study area: (I) utility poles in straight line direction, $(\mathrm{K})$ branch pole with cross-arms and different combination of pin-insulators and jumper wire locations, (R) corner pole with different combination of jumper wires location, (S) powerline switch disconnector and $(T)$ electric pole transformer.

Obr. 5. Základné rozdelenie stípov 22 kV prítomných v skúmanom území: (I) stíp na priamej línií, (K) odbočný stíp s viacerými konzolami a rôznymi umiestnením izolátorov a preponiek, (R) rohový stíp s rôznym umiestnením preponiek, (S) úsekový odpínač, (T) transformátor.

pylon-specific attributes were known, to identify proper technical specifications associated with the electrocution pattern. Altogether 16 individuals of imperial eagle and 14 of saker falcon were electrocuted on $22 \mathrm{kV}$ poles within our study area.

Within the range of $5 \mathrm{~km}$ buffer zone of all eagle and saker nests located in the study area, 11,267 dangerous poles (without proper mitigation measures) were identified and reported to the power supply companies concerned.

\section{Effect of different pole designs and bird size on e 1 e c t r o c u t i o n mortality} The effect of different poles designs was compared. During the field survey $61,32822 \mathrm{kV}$ poles were surveyed and finally 60,926 poles were included in the statistical analysis.

Sorting algorithm "k-means" was used to divide the utility poles into five groups according to the level of risk (Fig. 4) for birds (low, $p_{\text {kill }}=0.04 \pm 0.02$; low-medium, $\mathrm{p}_{\text {kill }}=0.12 \pm 0.03$; medium, $\mathrm{p}_{\text {kill }}=0.21 \pm 0.03$;

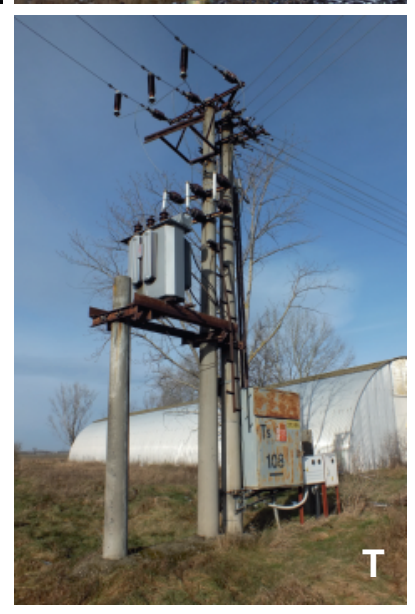

medium-high, $\mathrm{p}_{\text {kill }}=0.37 \pm 0.05 ;$ high, $\mathrm{p}_{\text {kill }}=0.57 \pm$ 0.09).

Five types of basic pole configuration (position and main type of console design) were identified (Fig. 5). Utility poles with one horizontal cross-arm and one/two pin insulators per conductor were the most numerous type in the $22 \mathrm{kV}$ grid in our study area $(60.08 \%)$ and were responsible for $42.04 \%$ of electrocuted individuals (0.03 carcass/pole). Poles with complex construction, such as corner or branch types with several levels of cross-arms, pin-insulators and combination of jumper wires, were the most dangerous; such types only formed $12.52 \%$ of all $22 \mathrm{kV}$ poles but were responsible for $34.72 \%$ of electrocution mortality ( 0.13 carcass/pole). 
Gális M, Nad’o L, Hapl E, Šmídt J, Deutschová L \& Chavko J: Comprehensive analysis of bird mortality along power distribution lines in Slovakia

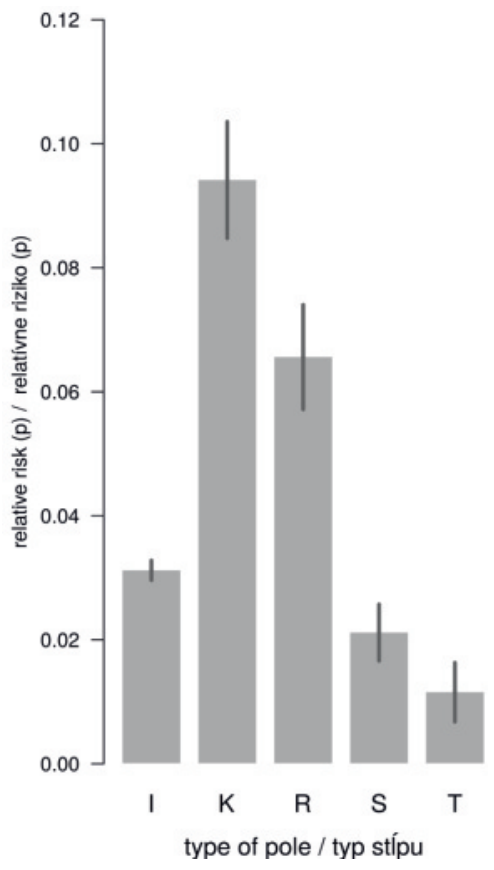

Fig. 6. Risk of various electrical pole configurations $(22 \mathrm{kV})$ to birds. Bar height represents the relative risk of electrocution on various types of poles. Vertical lines at each bar represent Blaker's exact confidence intervals (95\%) for risk level. Highest mortality risk was strongly associated with branch poles $(\mathrm{K})$ and corner poles (R) followed by utility poles in a straight line (I), switch disconnectors $(\mathrm{S})$ and electric pole transformers $(\mathrm{T})$.

Obr. 6. Rizikovost' rôznej konfigurácie elektrických stípov (22 kV) pre vtáky. Výška stípcov vyjadruje priemernú hodnotu rizika. Vertikálne čiary v každom stípci vyjadrujú Blakerove 95\%-tné intervaly spol'ahlivosti pre priemernú hodnotu rizika. Najvyššia rizikovost' bola prítomná u odbočných stípov (K) a rohových stĺpov (R). Nasledujú stípy na priamej línií (I), úsekové odpínače (S) a transformátory $(\mathrm{T})$.

The correlation between pole configuration and bird mortality was statistically significant comparing different types of pole designs (Fig. 6).

For better perspective and risk assessment, all bird victims of electrocution were grouped in three main size categories; small, medium and large $(22 \mathrm{kV})$ (Fig. 7). Medium and large bird species groups were composed mainly of birds of prey, owls and corvids.

I nflue nce of presence of u p$\mathrm{per}$ j u m per wire

One main pole component (jumper wire) was tested. Presence of jumper wires can increase the potential for avian electrocution due to the proximity between these energized parts (Ferrer et al. 1991, APLIC 2006). Ex-

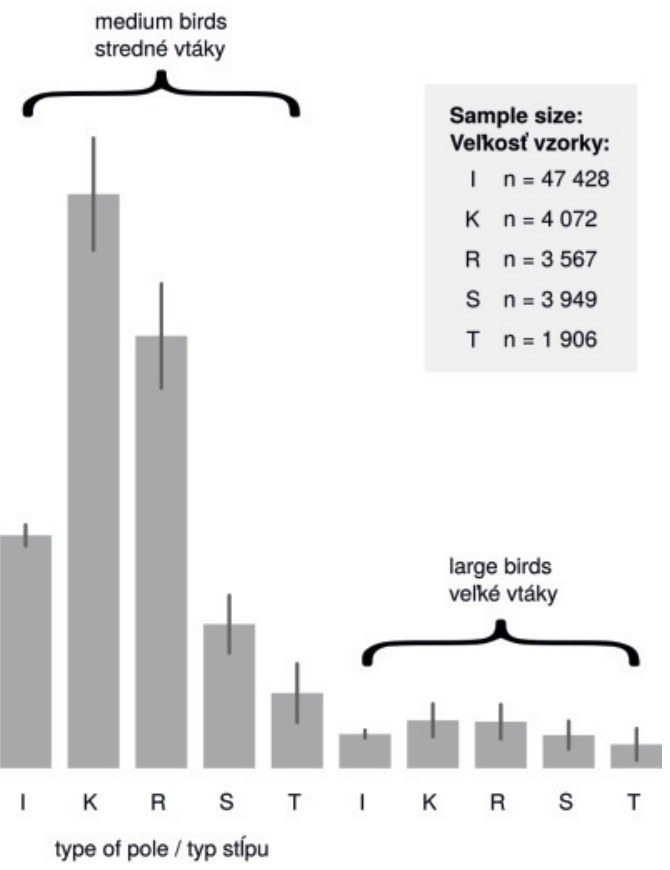

Fig. 7. Risk of poles $(22 \mathrm{kV})$ with regard to pole type and bird size category. Bar height represents the relative risk of electrocution on various types of pole. Vertical lines at each bar represent Blaker's exact confidence intervals (95\%) for risk level. Highest mortality risk was strongly associated with branch poles $(\mathrm{K})$ and corner poles $(\mathrm{R})$, especially for medium and less for large-sized birds.

Obr. 7. Rizikovost' stípov (22 kV) vo vzt’ahu ku typu stípu a vel'kostnej kategórie vtákov. Výška stĺpcov vyjadruje priemernú hodnotu rizika, pričom vertikálne čiary prechádzajúce stredom každého stĺpca vyjadrujú Blakerove 95 \%-tné intervaly spolahlivosti pre priemernú hodnotu rizika. Najvyššia mortalita bola prítomná u stredne vel'kých vtákov, a to najmä u odbočných stípov (K) a rohových stípov (R).

posed jumper wires were used mainly on corner and branch poles or on some poles in straight line (Fig. 8).

The risk increases especially if jumper wires are located above the cross-arms (Fig. 9).

In the end we did not observe statistically significant differences in risk rate between types of jumper wires (i.e. overlapping confidence intervals). Wide confidence intervals are an inevitable consequence of smaller sample size, so we cannot fully exclude the possibility that their true risk rates differ. Some difference between risk rates could be at least partially deduced from estimated values of mean risk rate (height of bars).

Of all surveyed $22 \mathrm{kV}$ poles, jumper wires in the upper position were identified in $4.5 \%$ (2,672 poles) but were responsible for $19.25 \%$ of all electrocution mortality. 

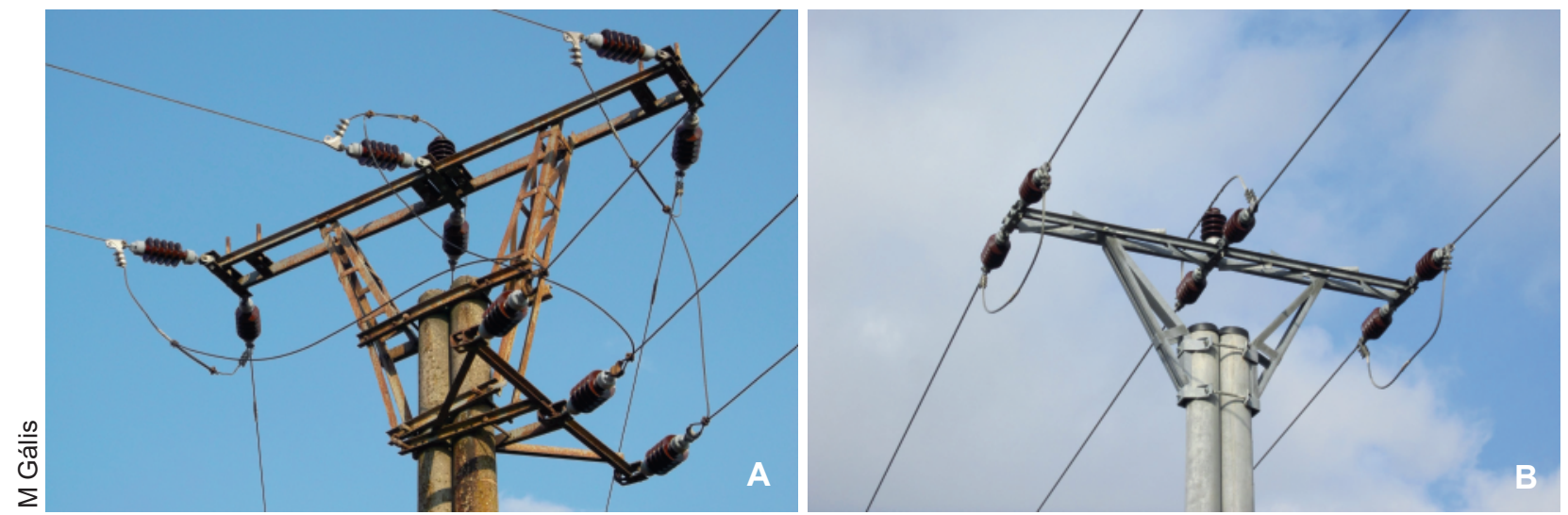

Fig. 8. Branch pole with many exposed jumper wire locations $(A)$ and three phase conductor design of pole in a straight line (B) with exposed jumper wire over the middle phase (many risky variations were identified, either over the middle and/or over one or both other phases).

Obr. 8. Odbočný stíp s rôznym umiestnením preponiek (A) a stíp na priamej línií s preponkou vedenou ponad strednú fázu (B). (identifikované boli mnohé kombinácie - ponad strednú a/alebo krajné fázy).

\section{Effect of bird protection}

$\mathrm{m}$ e a s u r e s

During the field survey, $78.24 \%$ of bird carcasses were found under non-retrofitted poles, 5.05\% under poles

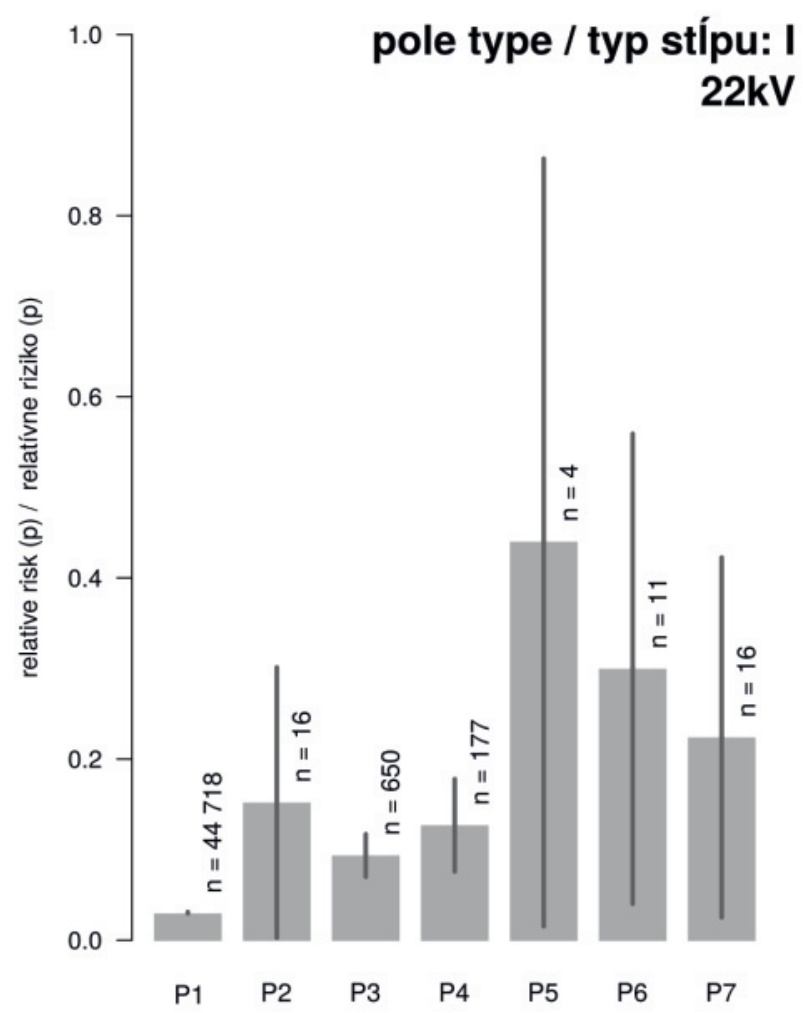

type of jumping wire / typ preponky with a damaged product and $3.07 \%$ under poles where the product was installed incorrectly. These poles together made up $62.44 \%$ of all $22 \mathrm{kV}$ poles surveyed.

Fig. 9. Risk of electrical poles to birds with regard to type of jumper wires. Bar length represents the relative risk of electrocution for various types of jumper wires. Vertical lines at each bar represent Blaker's exact confidence intervals (95\%) for risk level. All poles with the presence of jumper wires posed higher risk than basic utility poles without them. The wide confidence interval for some poles reflects the smaller sample in the surveyed area. Abreviations: P1 - without jumper wires, P2 - jumper wire passing over one pin-insulator at central phase, P3 - jumper wire passing over one pin-insulator et edge phase, P4 - jumper wire passing over two pin-insulator at central phase, P5 - jumper wire passing over two pin-insulator at central phase and one pin-insulator at edge phase, P6 jumper wire passing over one pin-insulator at central phase and one pin-insulator at edge phase, P7 - jumper wire passing over pin-insulators at all phases.

Obr. 9. Rizikovost' elektrických stípov so zameraním na typ preponky. Výška stĺpcov vyjadruje priemernú hodnotu rizika. Vertikálne čiary prechádzajúce stredom každého stípca vyjadrujú Blakerove 95 \%-tné intervaly spol'ahlivosti pre priemernú hodnotu rizika. Všetky stípy s prítomnými preponkami predstavujú pre vtáky vyššie smrtiace riziko a bežný stíp na priamej línií bez nich. Vel'mi široké intervaly spolahlivosti u niektorých typoch stípov sú spôsobené menším (reálne existujúcim) počtom takýchto stípov v skúmanom území (t.j. menšou vzorkou použitou pre výpočet). Skratky: P1 - bez preponky, P2 - preponka vedená strednou fázou cez jeden izolátor, P3 - preponka vedená krajnou fázou cez jeden izolátor, P4 - preponka vedená strednou fázou cez dva izolátory, P5 preponka vedená strednou fázou cez dva izolátory a krajnou fázou cez jeden izolátor, P6 - preponka vedená strednou a krajnou fázou cez jeden izolátor, P7 - preponka vedená všetkými fázami cez jeden izolátor. 

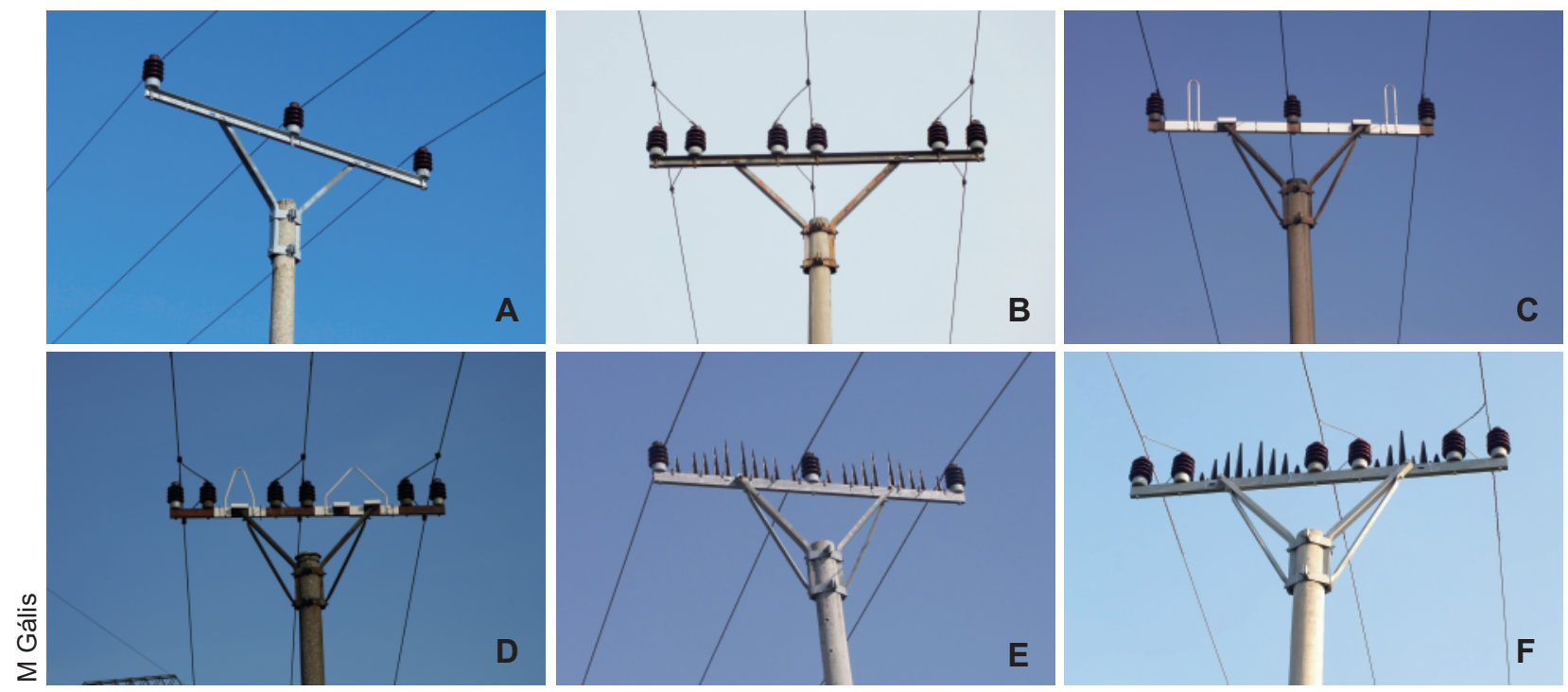

Fig. 10. Common utility pole with one (A) and two (B) pin-insulators per phase without insulation, with protective devices which allow birds to perch safely $(C)$ or prevent birds perching on the cross-arm but allow them to perch on top of the product (D) and plastic combs used as perch discourager $(\mathrm{E}, \mathrm{F})$.

Obr. 10. Stípy na priamej línií bez ošetrenia s jedným (A) a dvomi (B) podpernými izolátormi na jednu fázu, s ochrannými prvkami, ktoré umožňujú vtákom bezpečne dosadnút' (C) alebo im v dosadnutí bránia pričom im umožňujú sediet' na vrchole prvku (D) a plastové hrebene použité ako zábrana $(E, F)$, ktorá bráni dosadnutiu.

$13.64 \%$ of carcasses were located under poles which were retrofitted properly. Possible risk of electrocution was separately evaluated for (i) the most common 22 $\mathrm{kV}$ distribution pole $(\mathrm{A}, \mathrm{B})$ with a design of one/two insulators per phase conductor without retrofitting (ii) the first used (E, F) and (iii) the most common $(\mathrm{C}, \mathrm{D})$ protection measures (Fig. 10).

Statistically highest risk was identified for utility poles without insulation compared to the poles with present (safe perching or perch discourager) insulations. Utility poles with one phase per conductor posed higher risk than poles with two insulators per conductor. Lowest risk was identified for protective products which allow birds to perch safely on the cross-arm or on top of the product in comparison to products used as perch discourager (Fig. 11).
Different types of protective measures were also evaluated depending on the identified bird mortality for all species and separately for birds of prey (Tab. 2).

Not only the insulation products, but also changes in pole construction and position of pin-insulators and thus jumper wire location, could be rated as effective mitigation measures against electrocution. The most effective solution not only in Slovakia appears to be complete replacement of the construction with a new type, so-called Antibird and Ecobird consoles (Fig. 12). They are both effective thanks to the shape of the console $\left(45^{\circ}\right.$ angle of the arms) (Škorpíková et al. 2019). Another option is a suspension construction with hanging jumper wires.

Spatial distribution of the poles with recorded mortality incidents can help optimize the application of mit-

Tab. 2. Bird mortality on poles depending on mitigation measures.

Tab. 2. Mortalita vtákov v závislosti od ochranných prvkov.

\begin{tabular}{|c|c|c|c|}
\hline \multirow{2}{*}{$\begin{array}{l}\text { mitigation measures I } \\
\text { ochranné opatrenia }\end{array}$} & \multirow{2}{*}{$\begin{array}{l}\text { total number of poles I } \\
\text { celkový počet stípov }\end{array}$} & \multicolumn{2}{|c|}{$\begin{array}{l}\text { poles with mortality / stípy s mortalitou } \\
\text { all species / birds of prey / }\end{array}$} \\
\hline & & všetky druhy & dravce \\
\hline console insulation / izolácia konzoly & 6,846 & $92(1.34 \%)$ & $32(0.4 \%)$ \\
\hline plastic combs / plastové hrebene & 4,586 & $113(2.46)$ & $78(1.7 \%)$ \\
\hline plastic hat cover / plastové kryty & 701 & $102(14.5 \%)$ & $12(1.7 \%$ \\
\hline $\begin{array}{l}\text { plastic triangle / plastový trojuholník } \\
\text { other mitigation measures / ostatné ochranné opatrenia }\end{array}$ & 182 & $27(14.8 \%)$ & $11(6 \%)$ \\
\hline Antibird / Ecobird console / Antibird / Ecobird konzola & 1,631 & $16(0.9 \%)$ & $15(0.9 \%)$ \\
\hline pole with hanging insulators / stíp s vysiacimi izolátormi & 2,094 & $38(1.8 \%)$ & $6(0.3 \%)$ \\
\hline
\end{tabular}




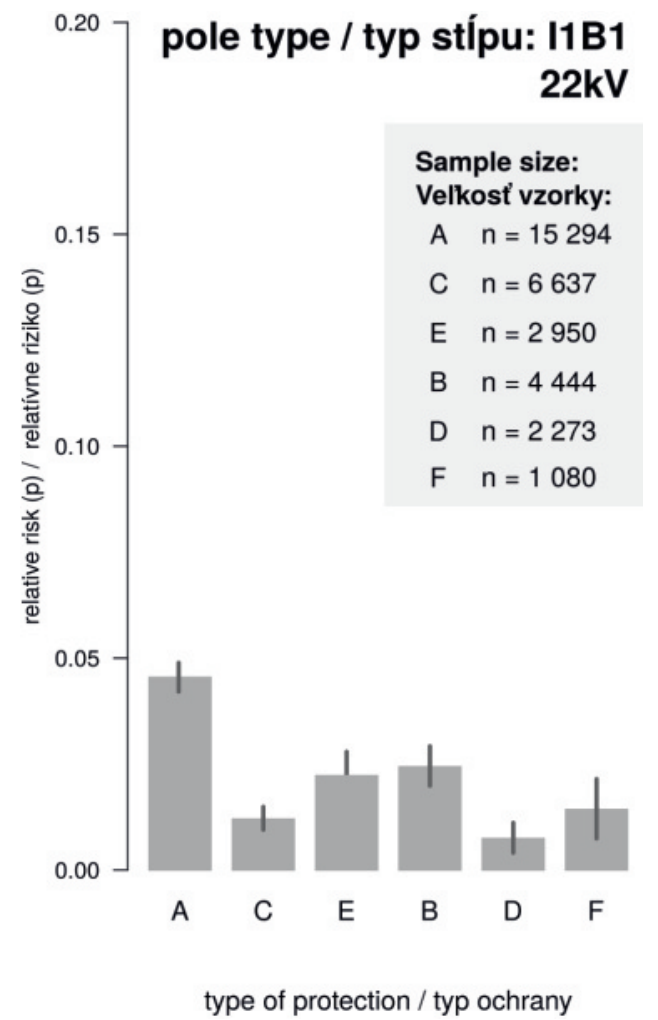

Fig. 11. Risk of various electricity poles (type I, 22kV) to birds with regard to presence/absence and type of protection. Bar height represents the relative risk of electrocution for various types of protection. Vertical lines at each bar represent Blaker's exact confidence intervals (95\%) for risk level. Abbreviations: Common utility pole with one (A) and two (B) pin-insulators per phase without insulation, with a protective product which allows birds to perch safely $(\mathrm{C})$ or prevent birds perching on the crossarm but allow them to perch on top of the product (D) and plastic combs used as perch discourager $(E, F)$.

Obr. 11. Riziko rôznych prevedení stípov typu I (22kV stíp na priamej línií) z hladiska prítomného/neprítomného ochranného prvku a jeho typu. Výška stípcov vyjadruje priemernú hodnotu rizika, pričom vertikálne čiary prechádzajúce stredom každého stípca vyjadrujú Blakerove $95 \%$-tné intervaly spolahlivosti pre priemernú hodnotu rizika. Skratky: Stípy na priamej línií bez ošetrenia s jedným $(A)$ and dvomi (B) podpernými izolátormi na jednu fázu, s ochrannými prvkami, ktoré umožňujú vtákom bezpečne dosadnút' $(C)$ alebo im $v$ dosadnutí bránia pričom im umožňujú sediet' na vrchole prvku (D) a plastové hrebene použité ako zábrana $(E, F)$, ktorá bráni dosadnutiu.

igation measures considering the risk of electrocution. This visualization (Fig. 13) can be used by power supply companies to focus their attention on the main "hot spots" with the highest risk of mortality.
Collision mortality and effect of power line construc$\mathrm{t}$ i o $\mathrm{n}$

Identified collisions made up $23.28 \%$ (908 ind.) of all detected carcasses belonging to 72 bird species and 14 bird orders. Fig. 14 shows the mortality in different taxonomic groups. Birds from the Corvidae family are listed separately from the other Passeriformes. Both types of line $(22 \mathrm{kV}$ and $110 \mathrm{kV})$ were responsible for collisions.

Anseriformes and Passeriformes made up 54.62\% of all identified collisions taken together. The percentage of raptors and corvids (3.85\%) colliding with power lines was small, compared to electrocuted individuals (45.88\%). In our results, the mute swan (Cygnus olor) was the most common bird detected with $20.8 \%$ (189 ind.) of all identified collisions $(\mathrm{n}=908)$. The second highest mortality was observed for the common pheasant (Phasianus colchicus) with 13.2\% (120 ind.) and third for the common blackbird (Turdus merula) with $6.3 \%$ (58 ind.).

In addition, habitats with oil-seed rape fields played an important role in this high mortality, especially if the power line was located close to such habitats (Fig. 15).

During our field survey the exact position of bird carcasses was recorded, to test the question whether the position of power lines relative to the cardinal points could influence bird mortality. Most carcasses (43.72\%) were located directly under the wires, so field assistants were not able to identify the exact direction of flight from their position. For the carcasses where the position could be identified, the prevailing trend was to the south $(20.48 \%)$ or north $(18.17 \%)$ from the power lines (Fig. $16)$.

I nfluence of the $n u m b$ e $r$ of c o n d u c t or l e ve $1 \mathrm{~s}$

Risk of collision for different vertical levels of medium voltage power lines $(22 \mathrm{kV})$ vs. high voltage power lines $(110 \mathrm{kV})$ was evaluated. Power lines of $110 \mathrm{kV}$ pose higher risk than lower $22 \mathrm{kV}$ lines (Fig. 17).

\section{Discussion}

Of the 4,353 victims identified under all surveyed power lines, the majority of them $(76.72 \%, 2,992$ ind.) was killed by electrocution, with $23.28 \%$ (908 ind.) due to collision with wires. 14 out of all 84 detected species are listed in the Red List of birds in Slovakia (Demko et al. 2013). In Bulgaria very similar results were obtained. 

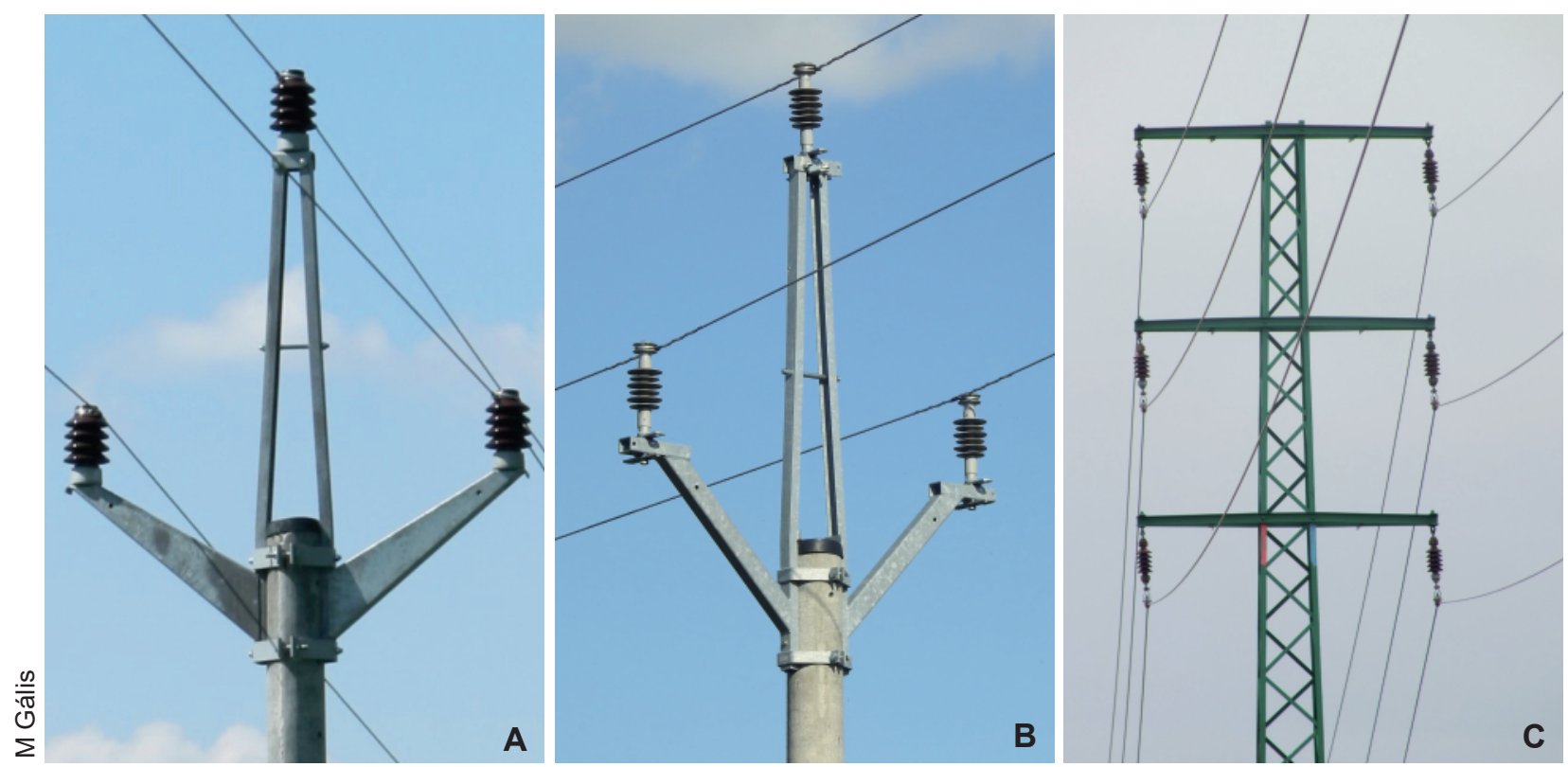

Fig. 12. Effective solutions for protecting birds from electrocution: Antibird (A), Ecobird (B) consoles and suspension pylon with hanging jumper wires $(\mathrm{C})$.

Obr. 12. Efektívne spôsoby ochrany vtákov pred zásahom prúdu: konzoly Antibird (A), Ecobird (B) a stožiar so závesnými preponkami (C).
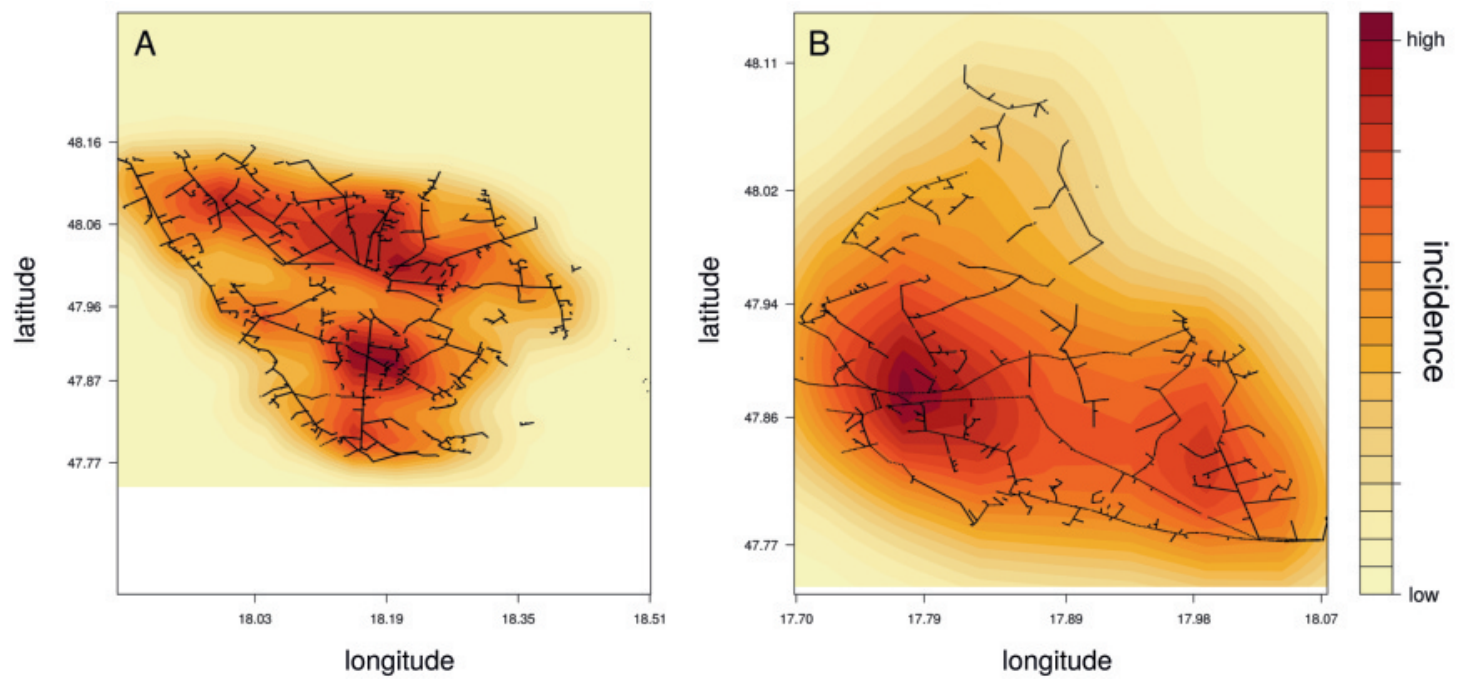

Fig. 13. Examples of possible visualization of incidence of bird mortality for specific areas (kernels for individual areas). Results of analysis suggest that incidences of electrocution tend to be concentrated in specific areas.

Obr. 13. Príklady možnej vizualizácie relatívnej frekvencie úhynov v skúmanom území (kernelové hustoty zachytávajúce frekvenciu úhynov pomocou farebnej škály). Výsledky týchto priestorových analýz naznačujú, že úhyny môžu byt’ v krajine koncentrovane do špecifických zón (tzv. "zóny smrti").

Electrocution was suspected for $77.1 \%$ of the detected carcasses, while $22.9 \%$ were suspected power line collisions (Demerdziev et al. 2009). Monitoring was carried out along a $139.3 \mathrm{~km}$ length of $20 \mathrm{kV}$ power line featuring 1,418 utility poles of various design. Even higher numbers and variety of bird mortality composition were identified in the Czech Republic. Electrocution was responsible for $88.24 \%$ of bird carcasses and collision for only $11.8 \%$ (Škorpíková et. al. 2019). Their field survey was carried out on a length of $6,429 \mathrm{~km} / 76,432$ poles of 


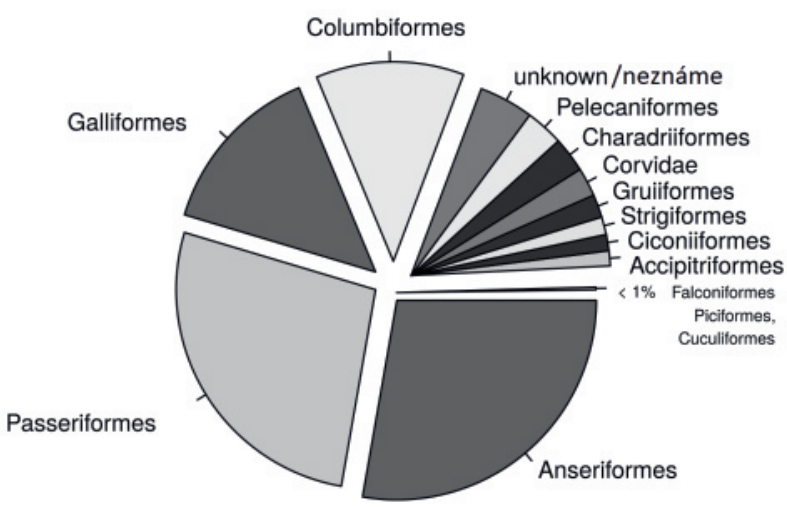

Fig. 14. Identified collisions in different taxonomic groups.

Obr. 14. Podiel úmrtnosti $v$ dôsledku nárazov pre jednotlivé taxóny.

$22 \mathrm{kV}$ power line. During the survey 1,326 bird carcasses of 60 species and 12 orders were found. The results of many studies also suggest that small bird carcasses disappear earlier and in a higher proportion than larger birds, often leaving few or no remains (Prosser et al. 2008, Ponce et al. 2010). These results were also confirmed in our observations by only occasional finds of small bird remains (feathers, bones). The real number of small bird carcasses is therefore most probably underestimated. Mortality rates can vary by season (Bevanger 1995, Harness \& Wilson 2001), with expected higher mortality rates for migratory birds during spring and fall migrations, and also for resident bird species (Loss et al. 2014). Given the characteristics of this study in which the majority of poles and pylons were only checked once in order to obtain a mortality range for the whole surveyed area, the data cannot be adjusted for total mortality rates with season patterns. Due to this limitation of our survey, we could expect that some utility poles or power line wires killed a large number of birds during the spring or fall migration periods, but since they were inspected only once and outside of these "high mortality rate" periods (therefore with zero mortality), these poles/wires appear to be safe for birds.

Strong correlation was identified between the spatial distribution and the riskiness of the utility poles. Zones with high incidence of bird mortality for individual geographical areas (so-called "death zones") were prepared. Observed electrocution incidence showed a patchy distribution across the study area, with high values in some specific areas. Our spatial analysis suggests that incidences of electrocution tend to be concentrated in specific areas. Bird mortality rates are not evenly distributed throughout the study area, suggesting the possible effect of spatially-related electrocutions. This clustering effect could be a result of different landscape composition and in the case of raptors also of the presence of prey sources.

The presence of identified bird carcasses may not reflect reliably the results of bird mortality surveys realized on range of $6,235 \mathrm{~km}$ of power lines.

We did not calculated correction factors for observer efficiency and scavenging rates influenced by season, vegetation type and habitat. The number of birds scavenged by predators (birds of prey, jackals, foxes, dogs and cats) was not assessed and monitored in our study,
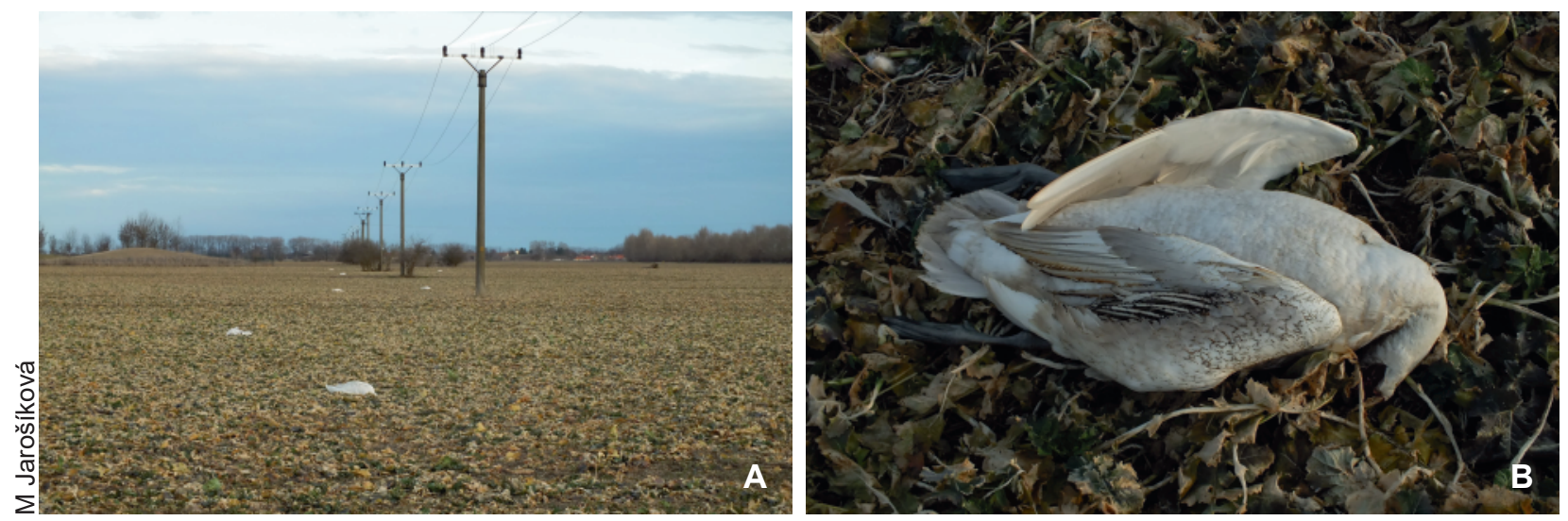

Fig. 15. Carcasses of mute swans in an oil-seed rape field used as foraging habitat, crossed by $22 \mathrm{kV}$ power line (A) and visible burn marks on feathers (B) after collision-electrocution.

Obr. 15. Úhyny labute vel'kej na repkovom poli, využívanom ako krmovisko (A), ktoré bolo križované vedením 22 kV a viditel'né stopy popálenín na perí (B) po náraze a následnom zásahu prúdom. 


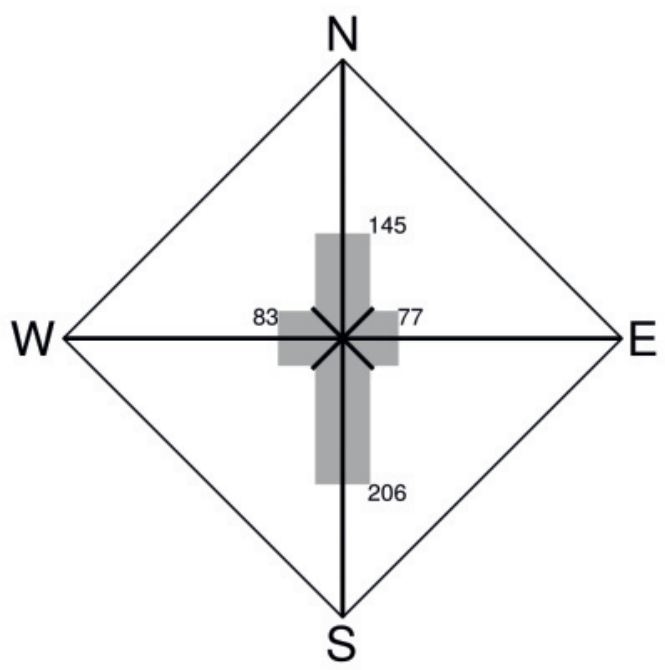

Fig. 16. Position of collision victims identified under surveyed power lines.

Obr. 16. Poloha úhynov po náraze identifikovaných na skúmaných vedeniach. although carcass removal by scavengers often biases the mortality surveys (Ponce et al. 2010) in very high initial removal rates among smaller carcasses, most of which disappeared within the first days (Prosser et al. 2008). The estimated mean mortality of birds killed on power lines in this study should therefore be considered as a minimum estimate. Additionally, some authors have recommended against making generalizations on total mortality rates for large geographical areas (Moleón et al. 2007, Guil et al. 2011).

E 1 e c trocution mortality

Altogether 2,992 individuals were killed by electrocution solely on $22 \mathrm{kV}$ poles $(60,296)$. Electrocuted birds were found below $3.5 \%$ (2,016 poles) of $22 \mathrm{kV}$ poles. For example in a study undertaken in Spain (Janss \& Ferrer 2001), a dead bird was located under $5.3 \%$ of power poles. Very similar numbers are reported in Bulgaria, where electrocuted birds were concentrated under $4.6 \%$ of all surveyed poles (Demerdziev et al.

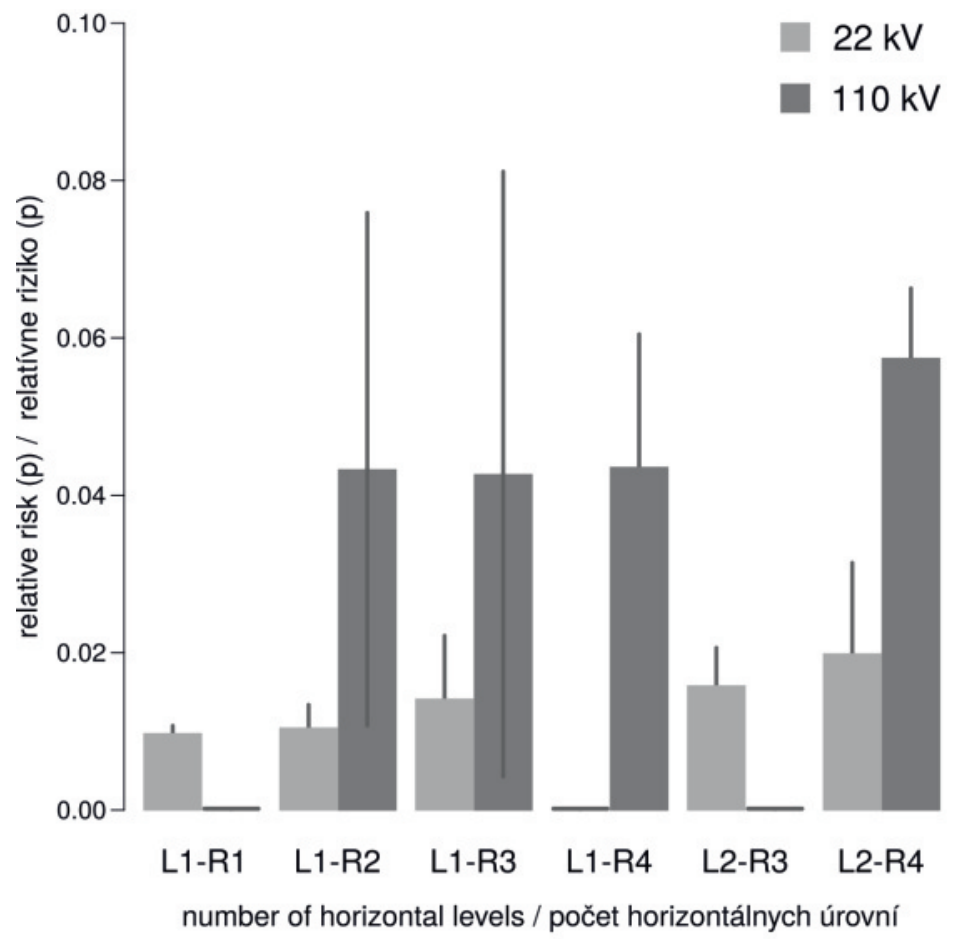

Fig. 17. Risk of power line to birds with regard to number of horizontal levels. Barplot height represents the relative risk of collision for various types of horizontal levels. Vertical lines at each bar represent Blaker's exact confidence intervals (95\%) for risk level. Abbreviations: $L$ - number of voltage circuits; $R$ - number of conductor levels.

Obr. 17. Rizikovost' vedenia pre vtáky vzhl'adom k počtu horizontálnych rovín. Výška stípcov vyjadruje priemernú hodnotu rizika. Vertikálne čiary prechádzajúce stredom každého stĺpca vyjadrujú Blakerove 95 \%-tné intervaly spol'ahlivosti pre priemernú hodnotu rizika. Skratky: $L$ - počet okruhov vedenia; $R$ - počet úrovní vodičov. 
2009), and only $1.24 \%$ of all poles (718 pylons with 826 electrocuted birds) were responsible for mortality in a study carried out in the Czech Republic (Škorpíková et al. 2019).

According to our results, the number of dead birds per year and per utility pole was estimated as 0.05 . A very similar number was presented in a study by Loss et al. (2014), with a median annual rate of 0.03 birds per distribution pole.

Power lines cause a large proportion of mortality for some species, especially raptors (Harness \& Wilson 2001, Guil et al. 2011). Corvids and birds of prey often use poles for roosting or hunting, as they are often the tallest structures in grassland and open agricultural land (APLIC 2006, Demeter et al. 2018). These two groups are therefore often evaluated together. Corvids and birds of prey represented $85.25 \%$ of all identified electrocutions in our study. Raptors were associated with $40 \%$ of all identified victims of electrocution. In Bulgaria, crows and birds of prey represented more than $53 \%$ of detected electrocutions (Demerdziev et al. 2009), while in the Czech Republic this percentage is even higher, up to $87.77 \%$ (Škorpíková et al. 2019). Our results are similar to those in other studies, such as Bayle (1999) in France where corvids and birds of prey made up $85 \%$ of electrocution records, and a study in Spain, where crows and birds of prey represented more than $80 \%$ of all identified electrocutions (Guyonne et al. 2001).

In our results the common buzzard was the bird of prey most frequently detected, and was involved in $85.39 \%$ (1,023 ind.) of all identified raptor electrocutions $(\mathrm{n}=1,198)$, in $34.19 \%$ of all electrocutions and in $26.23 \%$ of all recorded bird carcasses (electrocution + collision). Second highest mortality was observed for the Eurasian magpie with $20.08 \%$ (601 ind.) and third for the hooded crow with $7.08 \%$ (212 ind.). Very similar composition of bird carcasses was published by Škorpíková et al. (2019). The common buzzard was the most frequently detected victim of electrocution (39.48\%) followed by the Eurasian magpie (17.55\%) and common kestrel (Falco tinnunculus) (13.89\%). Based on the results of Janss \& Ferrer (2001), most common casualties in Spain were the common raven (Corvus corax) (16.0\%), jackdaw (Corvus monedula) $(10.2 \%)$ and common buzzard (7.7\%). In Hungary, of all identified electrocutions $(n=2,777)$ the common buzzard was the most often detected victim (18.9\%), followed by the Eurasian magpie (13.8\%) and white stork (Ciconia ciconia) (13.6\%) (Fidlóczky et al. 2014). During the monitoring in a recent study done in
Hungary (01/2004-12/2014), volunteer researchers surveyed 57,486 pylons. 3,400 bird carcasses of at least 79 species were identified as electrocuted (Demeter et al. 2018). Due to relative similar types of pylons in the listed countries (Slovakia, Czech Republic and Hungary), the different proportions of electrocuted species most likely reflect the differences in composition of bird populations in the surveyed habitats. Probably in most of our cases, the electrocution of small Passeriformes and Columbiformes occurred when these perched in higher numbers on support (pin) insulators or close to exposed jumper wires located on branch poles and transformers. This relatively small unprotected area can be lethal for this group of birds.

In our study, two endangered species were also separately evaluated as victims of electrocution, identified during 12/2014-09/2019: the imperial eagle (16 identified carcasses) and saker falcon (14 identified carcasses). The imperial eagle population was composed of at least 90-95 breeding pairs and for the saker falcon 3032 breeding pairs for the whole of Slovakia (Chavko 2018). Both are endangered especially by human activities, but one of the main causes of mortality is electrocution on distribution power lines (Heredia 1996, Bagyura et al. 2002, Nagy \& Demeter 2006, Karyakin et al. 2009, Chavko 2010, Horváth et al. 2011, Prommer et al. 2012, Kovács et al. 2014, Nemček et al. 2014, Demeter et al. 2018).

Young imperial eagle and saker falcon individuals are especially common victims of electrocution in Slovakia (Nemček 2014, 2016, Veselovský 2018), corresponding to results from other countries (Prommer et al. 2012, Kovács et al. 2014, Stoychev et al. 2014). Proximity to nests of non-insulated medium-voltage poles poses a fatal risk for many young and inexperienced birds with lower ability to fly, as they try to take offor land on poles (APLIC 2006). Many of the nesting pairs of saker falcon and imperial eagle have gradually resettled from the foothills to the neighbouring agrocenoses, with higher risk of possible electrocution and/or collisions (Danko \& Chavko 2002, Chavko 2002, 2010). The negative impact of electrocution on endangered raptors, with many other direct and indirect mortality factors, can lead to great reduction in population strength and density. This is especially for species where the loss of a few or even one individual may impact a local population or the overall population viability (Crowder 2000).

Necessary mitigation measures were also adopted by distribution power-line operators during the LIFE 
Gális M, Nad’o L, Hapl E, Šmídt J, Deutschová L \& Chavko J: Comprehensive analysis of bird mortality along power distribution lines in Slovakia

Energy project; one third of medium-voltage poles around the nests of both species were insulated with effective plastic devices to eliminate electrocutions. Moreover, jumper wires were relocated to new underslung and thus safe positions. This was also done on metal poles during the LIFE Energy project.

Corner and branch poles were significantly more dangerous for birds than utility poles in straight lines. Bird mortality was lowest for power-line switch disconnectors and pole-borne transformers, which are often situated at the edges of human settlements or are part of urban/industrial areas, with lower presence of birds. Corner and branch poles on medium-voltage lines were also identified as the most dangerous in a survey done in the Czech Republic (Škorpíková et al. 2019). Similar results are reported also in Bulgaria: metal branch poles featuring jumper wires accounted for $54.3 \%$ of total detected electrocution mortality (Demerdziev et al. 2009). Anchor poles in particular have been shown to pose a significant electrocution risk to birds, particularly due to the configuration of the jumper wires (Dixon et al. 2013, 2017, Škorpíková et al. 2019).

Medium and large bird species were significantly affected, as they are more likely to make simultaneous contacts with unprotected parts of the pole construction (Dwyer \& Mannan 2007, Dwyer et al. 2015). These results are in strong correlation with our findings, as corvids and birds of prey made up $85.25 \%$ of all identified electrocutions. The proposed mitigation measures should therefore be generally focused especially on medium-sized birds and on corner and branch pole types. Medium and large perching birds can easily bridge the gap between wires, consoles and jumper wires, which are in much closer proximity on corner and branch poles. The electrocution of large birds such as raptors, owls and corvids can also cause damage and sometimes result in interruption of power distribution. Large electrocuted birds (eagles, storks) very often remain in place, resulting in failure of the circuit as the operating system tries to re-energize the grid.

Electrocution may occur even on retrofitted poles. The current quality status of already installed bird protective measures (O.K., damaged or wrong application) was also evaluated and compared with mortality due to electrocution. The highest percentage $(78.24 \%)$ of bird carcasses were found under non-retrofitted poles. The rest consisted of $5.05 \%$ under poles with a damaged product and $3.07 \%$ under poles where the product was installed incorrectly.
The risk of possible electrocution is significantly higher on utility poles without insulation, especially for construction types with one pin-insulator per phase conductor. Plastic insulators which allow birds to perch safely on the console are more effective than plastic combs. Plastic combs (green or black) were the first and became the most widely-used bird protection measure in Slovakia. Many medium and large bird species were found electrocuted under a pole with a comb installed during our study, even if the product was in good condition and still fully covering the console. More species were electrocuted on damaged combs, especially if the remains of the product were located in the middle of two insulators, forcing birds to perch closer to the phase conductors or other energized parts. In the Czech Republic (Škorpíková et al. 2019) this protection measure was also replaced for being non-effective. A study by Dwyer et al. (2017) evaluated 52 retrofitted poles where 56 birds, including 17 golden eagles, were electrocuted due to incorrect installation of the product. The products used to mitigate the electrocution risk should be made from durable, long-lasting materials and should be installed properly to ensure protection of birds. If they are damaged or incorrectly installed, they are useless and more dangerous than non-insulated poles.

\section{Collis i o n mortality}

Altogether 72 bird species and 14 bird orders were identified as victims of collision in our study. Anseriformes and Passeriformes made up more than half of all identified collision victims together. The percentage of raptors and corvids colliding with power lines was very small, compared to electrocuted individuals. The highest mortality $(23.2 \%)$ was recorded for the mute swan. These results were not surprising, because large birds with slow manoeuvrability (high wing loading and low wing aspect ratio) are especially vulnerable to collision (Bevanger 1998, Erickson et al. 2001, Crowder \& Rhodes 2002, Manville 2005, Jenkins et al. 2010). For this reason swans are among the commonly recorded victims (Perrins \& Sears 1991, Brown 1993, Mathiasson 1993, Frost 2008, Kelly \& Kelly 2009, Gális et al. 2018a, Franson et al. 2019). Other studies have shown very similar or higher numbers of casualties for the mute swan, accounting for $30-40 \%$ of all recorded deaths in Coleman et al. (2001), and up to $46 \%$ of deaths in study by Spray (1991). Many reports of mute swan collisions with power lines are available from the United Kingdom. The study by Frost (2008) presented a significant level of mortality in spring for mute swans 
colliding with overhead $132 \mathrm{kV}$ power lines. The study by Perrins \& Sears (1991) showed that $22 \%$ of all reported carcasses of swans were the result of collisions with wires. In Sweden between 19-38\% of ringed mute swans were killed by collision with electrical wires (Mathiasson 1993). One input factor which could influence bird collision susceptibility (though not a significant factor in determining the risk of collision) is elevated blood lead level. Studies by Kelly \& Kelly (2009) suggest that mute swans with elevated but moderate blood lead levels suffer an increased risk of collision, while those with intermediate to high levels have a much reduced risk of collision, possibly because they are too weak to fly. The large number of dead mute swan individuals in our study area was probably a result of their behaviour, as they fly mainly in flocks. They also require long stretches for take-off and landing. Moreover, species with narrow visual fields (e.g. swans, ducks, herons) are at higher collision risk as they can not see the wires from a certain angle (Martin \& Shaw 2010, Martin 2011).

Positive effect of the height of tree growth on collision probability was identified during our field survey. On one particular $22 \mathrm{kV}$ power line with a total length of $600 \mathrm{~m}$, of which $250 \mathrm{~m}$ was in the neighbourhood of trees, all collisions (18 mute swans) were recorded only on the remaining $350 \mathrm{~m}$ without the presence of nearby tree growth producing a lower probability of collision. The correlation of presence of nearby tree growth was studied by Bevanger \& Broseth (2004), where collision spots generally had lower trees compared to places with tall trees alongside power lines, which were without any recorded collisions.

Although different bird species fly at differing heights above the ground, there is a prevailing consensus that the lower power-line cables are to the ground, the better they are for preventing bird collision. There is also a consensus that reduced vertical separation of cables is preferred as it poses less of an "obstacle" for birds to collide with. Horizontal separation of conductors is therefore preferred (Prinsen et al. 2011). Based on our findings, $110 \mathrm{kV}$ power lines pose a higher risk than lower $22 \mathrm{kV}$ lines.

Increasing the number of conductor levels leads to higher risk of possible collision. Our results are in line with those of many studies (Drewitt \& Langston 2008, Jenkins et al. 2010). On the other hand, the effect of vertical levels was not in correlation with collision rates in studies by Infante et al. (2005) and Neves et al. (2005). Higher risk could be correlated with the presence of a shield wire on $110 \mathrm{kV}$ lines. It is the highest wire and can be difficult for birds to see (APLIC 2012) because of its small diameter compared to phase conductors. The number of vertical levels can pose greater risk, but many studies reporting the positive/ negative effects of number of vertical levels of wire were reviewed in the excellent study by Bernardino et al. (2018), where the authors conclude that there is little scientific evidence in support of these effects due to the practical difficulties involved in testing them (APLIC 2012).

Orientation of power lines relative to biological characteristics (e.g. flight behaviour, season, habitat and habitat use) and environmental conditions (e.g. topographical features and weather patterns) can also influence collision risk. Brown (1993) suggested that north-south orientation of lines increased collision frequency for cranes and waterfowl in the San Luis Valley, Colorado, because birds crossing them on an easterly heading were often subjected to prevailing westerly winds. More studies from different sites are needed to test whether or not the risk of collision could be increased by sun glare, as bird collision risk could also be correlated to sun glare, mainly when birds undertake flights over lines oriented in west-east pattern. The carcasses whose position could be identified in our study, and whose prevailing position was south or north from power lines, could indicate that birds flying in northsouth direction, and thus into the sun, could be blinded by the glare and thus collide with the wires. Just after sunrise and before sunset the sun can shine directly into birds' eyes, leaving many flying into a glare. This glare can make it much harder to see power lines ahead, turning them into potential hazards creating an added risk for birds.

\section{Conclusions}

The main focus of this study was on collision and electrocution, to recognize the range of the problem and its relevance for different bird species, power lines and pole/ pylon designs. The field monitoring was the most comprehensive and systematic study of its kind ever carried out in Slovakia. The majority of all identified bird victims was killed by electrocution, especially corvids and birds of prey (including the endangered saker falcon and imperial eagle). Only medium-voltage lines $(22 \mathrm{kV})$ were responsible for electrocution and these lines killed birds primarily by electrocution rather than collision. The risk of possible electrocution was correlated to the size of birds. Medium and large bird species were most 
Gális M, Nad’o L, Hapl E, Šmídt J, Deutschová L \& Chavko J: Comprehensive analysis of bird mortality along power distribution lines in Slovakia

affected as they consist mainly of birds of prey, owls and corvids, which very often use poles for perching or hunting. Because of their bigger wing span and/or other body parts, larger bird species can easily short-circuit the energized parts and/or phase conductors on poles compared to smaller bird species. Poles with complex construction, such as corner or branch types with several levels of cross-arms, pin-insulators and combination of jumper wires, were much more dangerous than poles in straight lines, switch disconnectors and poles bearing transformers. The risk of possible electrocution was significant higher for utility poles without insulation than for poles with effective protection devices, but only if they are in good condition and installed in the proper way. The most dangerous medium-voltage power poles identified in our survey were insulated to prevent electrocution, especially in buffers around the nests of saker falcons and imperial eagles.

Much fewer bird individuals (but more bird species) were killed by collision than electrocution. The incidence of raptors and corvids colliding with power lines was very small, compared to electrocuted individuals and large heavy-bodied species such as the mute swan, which had the highest mortality rate recorded in our study area. Habitats with oil-seed rape fields played an important role in this high mortality, especially if the power line was located close to them. Increasing vertical separation of cables posed more of an 'obstacle' for birds to collide with.

Based on the results from our field survey (12/2014 02/2016), 13 mitigation plans were designed for the project area with recommendations of particular measures for each SPA and neighbouring areas, including the installation of bird flight diverters on sections of power lines with the highest risk of possible collisions. 1,120 $\mathrm{km}$ of power lines were included in the group in the highest category $(17.9 \%$ of all inspected power lines) concerning the relative risk of collision evaluation. Of these, $77 \mathrm{~km}$ were given the highest priority and were provided with increased visibility by means of 8,000 bird flight diverters within the LIFE Energy project period.

The risk posed by power lines to birds is still an underestimated reason for their mortality in some countries or areas, and the data are either missing or absolutely insufficient. The bird vs. power line issue is dealt with in a large number of reports and publications from various countries. In some countries only sporadic data have been recorded by local experts and the general public, and up to now the phenomenon of collisions has not been credibly studied and evaluated worldwide. More knowledge about the factors increasing collision and electrocution mortality rates will produce essential guidelines for proper bird-friendly measures in the case of existing and/or for the construction of new power lines. In Slovakia a special legal obligation for this was imposed in 2003, based on Law No. 543/2002 Coll. on the Conservation of Nature and Landscape:

(i) Everyone building or doing a reconstruction of an aerial power line according to a plan is required to use a technical solution which prevents the electrocution of birds.

(ii) If cases of bird mortality are proven on a power line or telecommunications device, the Nature Conservancy Authority can decide that the operator of it must undertake technical measures to prevent such incidents.

Any problems so far have always been resolved after mutual communication. Construction of safer crossarms has been adopted, or they have been insulated to protect birds from electrocution. Diverters are being installed to prevent collisions. Since implementation of the LIFE Energy project, the electricity companies have started considering the protection of birds even prior to (re)construction. The good relationship, cooperation and trust which we have built with the electricity companies are now far more effective, useful and important than the obligations set by the law.

\section{References}

APLIC (Avian Power Line Interaction Committee) 2006: Suggested practices for avian protection on power lines: the state of the art in 2006. Edison Electric Institute, APLIC, and the California Energy Commission, Washington, DC and Sacramento.

APLIC (Avian Power Line Interaction Committee) 2012: Reducing Avian Collisions with Power Lines: The State of the Art in 2012. Edison Electric Institute and APLIC. Washington, D.C.

Bahat O 2008: Wintering black storks (Ciconia nigra) cause severe damage to transmission lines in Israel: a study on the risk and mitigation possibilities. In: Proc. of the EDM and EPRI Internatl. Conf. on Overhead Lines. 31 March-3 April 2008. Fort Collins, Colorado.

Bagyura J, Szitta T, Haraszthy L, Firmánszky G, Viszló L, Kovács A, Demeter I \& Horváth M 2002: Population increase of imperial eagle (Aquila heliaca) in Hungary between 1980 and 2000. Aquila 107-108: 133-144. 
Bayle P 1999: Preventing birds of prey problems at transmission lines in Western Europe. Journal of Raptor Research 33: 43-48.

Bernardino J, Bevanger K, Barrientos R, Dwyer J, Marques A, Martin R, Shaw J, Silva J \& Moreira F 2018: Bird collisions with power lines: State of the art and priority areas for research. Biological Conservation 222: 1-13. DOI: 10.1016/j.biocon. 2018.02.029.

Bevanger K 1995: Estimates and population consequences of tetraonid mortality caused by collisions with high tension power lines in Norway. Journal of Applied Ecology 32: 745-753.

Bevanger K 1998: Biological and conservation aspects of bird mortality caused by electricity power lines: a review. Biological Conservation 86: 67-76. DOI: 10.1016/S0006-3207(97)00176-6.

Bevanger K \& Brøseth H 2004: Impact of power lines on bird mortality in a subalpine area. Animal Biodiversity and Conservation 27: 67-77.

Blaker H 2000: Confidence curves and improved exact confidence intervals for discrete distributions. Canadian Journal of Statistics 28 (4): 783-798.

Brown WM 1993: Avian collisions with utility structures: biological perspectives, 12-13. In: APLIC, Proc. of the Intl. Workshop on Avian Interactions with Utility Structures, 13-16 September 1992, Miami, Florida. Electric Power Research Institute and Avian Power Line Interaction Committee, Palo.

Chavko J 2002: Sokol rároh (Falco cherrug). [Saker falcon], 214-216. In: Danko Š, Darolová A \& Krištín A (eds): Rozšírenie vtákov na Slovensku [Distribution of birds in Slovakia]. Veda, Bratislava. [In Slovak with English summary]

Chavko J 2010: Trend and conservation of saker falcon (Falco cherrug) in western Slovakia between 1976 and 2010. Slovak Raptor Journal 4: 1-22. DOI: 10.2478/v10262-012-0040-4.

Chavko J 2018: Správy pracovných skupín za rok 2017 pre orla královského a sokola rároha [Reports of working groups for 2017 for the imperial eagle and saker falcon]. Dravce a Sovy 14: 4-13. [In Slovak]

Coleman A, Coleman J, Coleman P \& Minton C 2001: A 39 year study of a mute swan Cygnus olor population in the English Midlands. Ardea 89: 123-133.

Crowder MR 2000: Assessment of devices designed to lower the incidence of avian power line strikes. $\mathrm{PhD}$ Thesis. Purdue University, West Lafayete.

Crowder MR \& Rhodes OE 2002: Relationships between wing morphology and behavioural re- sponses to unmarked power transmission lines: 403410. In: Goodrich-Mahoney JW, Mutrie DF \& Guild CA (eds), The Seventh International Symposium on Environmental Concerns in Rights-of-Way Management. Elsevier, Boston.

Danko Š \& Chavko J 2002: Orol král'ovský (Aquila heliaca) [Imperial eagle]. 199-200. In: Danko Š, Darolová A \& Krištín A (eds): Rozšírenie vtákov na Slovensku [Distribution of birds in Slovakia]. Veda, Bratislava. [In Slovak with English summary]

Demerdzhiev D, Stoychev S, Petrov T, Angelov I \& Nedyalkov N 2009: Impact of power lines on bird mortality in Southern Bulgaria. Acta Zoologica Bulgarica 61: 175-183.

Demerdzhiev D 2014: Factors Influencing Bird Mortality Caused by Power Lines within Special Protected Areas and undertaken Conservation Efforts. Acta Zoologica Bulgarica 66: 411-423.

Demeter I, Horváth M, Nagy K, Gorogh Z, Tóth P, Bagyura J, Solt S, Kovács A, Dweyer J \& Harness R 2018: Documenting and reducing avian electrocutions in Hungary: A conservation contribution from citizen scientists. The Wilson Journal of Ornithology 130: 600-614. DOI: 10.1676/17-031.1.

Demko M, Krištín A \& Puchala P 2013: Červený zoznam vtákov Slovenska. [Red list of birds in Slovakia]. Tichodroma 25: 69-78. [In Slovak]

Dixon A, Maming R, Gunga A, Purev-Ochir G \& Batbayar N 2013: The problem of raptor electrocution in Asia: Case studies from Mongolia and China. Bird Conservation International 23: 520-529. DOI: 10.1017/S0959270913000300.

Dixon A, Rahman L, Galtbalt B Gungaa A, Sugarsaikhan B \& Batbayar N 2017: Avian electrocution rates associated with density of active small mammal holes and power-pole mitigation: Implications for the conservation of Threatened raptors in Mongolia. Journal for Nature Conservation: 14-19. DOI: 36. 10.1016/j.jnc.2017.01.001.

Drewitt AL \& Langston RHW 2008: Collision effects of wind-power generators and other obstacles on birds. Annals of the New York Academy of Sciences 1134: 233-266. DOI: http://dx.doi.org/10.1196/annals. 1439.015.

Dwyer JF \& Mannan RW 2007: Preventing raptor electrocutions in an urban environment. Journal of Raptor Research 41: 259-267.

Dwyer J, Kratz G, Harness R \& Little S 2015: Critical dimensions of raptors on electric utility poles. Journal of Raptor Research 49: 210-216. DOI: 
Gális M, Nad’o L, Hapl E, Šmídt J, Deutschová L \& Chavko J: Comprehensive analysis of bird mortality along power

distribution lines in Slovakia

10.3356/0892-1016-49.2.210.

Erickson WP, Johnson GD, Strickland MD, Sernka KJ \& Good RE 2001: Avian collisions with wind turbines: a summary of existing studies and comparisons to other sources of avian collision mortality in the United States. Western Ecosystems Technology, Inc., Cheyenne, Wyoming.

Erickson WP, Johnson GD \& Young DPJ 2005: A summary and comparison of bird mortality from anthropogenic causes with an emphasis on collisions, 1029-1042. In: Ralph CJ \& Rich TD (eds): Bird Conservation Implementation and Integration in the Americas: Proceedings of the Third International Partners in Flight Conference. 2002 March 20-24; Asilomar, California, Volume 2 Gen. Tech. Rep. PSW-GTR-191. U.S. Dept. of Agriculture, Forest Service, Pacific Southwest Research Station, Albany, CA.

Fidlóczky J, Bagyura J, Nagy K, Tóth P, Szitta T \& Haraszthy L 2014: Bird conservation on electricpower lines in Hungary: Nest boxes for saker falcon and avian protection against electrocutions. Projects' report. Slovak Raptor Journal 8(2): 87-95. DOI: 10.2478/srj-2014-0010.

Ferrer M, De La Riva M \& Castroviejo J 1991: Electrocution of raptors on power lines in southwestern Spain. Journal of Field Ornithology 62: 54-69.

Ferrer M 2012: Birds and power lines. From conflict to solution. Endesa SA and Fundación Migres, Sevilla.

Fransson T, Jansson L, Kolehmainen T \& Wenninger T 2019: Collisions with power lines and electrocutions in birds - an analysis based on Swedish ringing recoveries 1990-2017. Ornis Svecica 29: 37-52. DOI: 10.34080/os.v29.19731.

Frost D 2008: The use of 'flight diverters' reduces mute swan Cygnus olor collision with power lines at Abberton Reservoir, Essex, England. Conservation Evidence 5: 83-91.

Gadziev AM 2013: Death of Birds of Prey on Power Lines in Daghestan. Raptors Conservation 27: 235240.

Gális M, Deutschová L, Šmídt J, Hapl E \& Chavko J 2016: Vysoká cena za pohodlie alebo rizikovost' elektrických vedení pre vol'ne žijúce druhy vtákov [The high price of human comfort or the riskiness of power line for bird species], 77-79. In: Krumpalová $\mathrm{Z}$, Zigová M, Tulis $\mathrm{F}$ (eds), Zborník príspevkov z vedeckého kongresu "Zoológia 2016 " [Proceeding from the science congress "Zoology 2016"], Univerzita Konštantína Filozofa v Nitre, Nitra. [In Slov- ak with English Summary]

Gális M, Deutschová L, Šmídt J, Hapl E \& Chavko J 2017a: Vplyv konštrukčného prevedenia konzoly stĺpu $22 \mathrm{kV}$ a jej ošetrenia na úmrtnost' vtákov [The effect of configuration of corss-arm of $22 \mathrm{kV}$ and mitigation devices on bird motality], 59-60. In: Bryja J, Horsák M, Horsáková V, Řehák Z \& Zukal J (eds.): Zoologické dny Brno. Sborník abstraktů z konference [Zoological Days. Proceedings abstracts from conference], Institute of Vertebrate Biology Czech Academy of Sciences, Brno.[In Slovak]

Gális M, Deutschová L, Šmídt J, Hapl E \& Chavko J 2017b: Nárazy vtáctva do elektrických vedení fakty a riešenia [Bird collisions with power lines facts and solutions], 20-21. In: Kropil R \& Lešo P (eds), Aplikovaná ornitologia. Zborník abstraktov [Applied ornithology. Book of the abstracts] 2017. TU, Zvolen [In Slovak]

Gális M, Deutschová L, Šmídt J, Hapl E \& Chavko J 2018a: Labut' vel'ká - obet' nárazov do elektrických vedení [The mute swan - victim of bird collisions], 73. In: Bryja J \& Solský M (eds), Zoologické dny. Sborník abstraktů z konference [Zoological Days. Proceedings abstracts from conference], Institute of Vertebrate Biology Czech Academy of Sciences, Brno. [In Slovak]

Gális M, Deutschová L, Šmídt J, Hapl E \& Chavko J 2018b: Bezpečne a plynulo vd'aka projektu LIFE Energia [Safe flights - thanks to LIFE Energy project], 39. In: Kubovčík V \& Stašiov S (eds), Zborník abstraktov $\mathrm{Z}$ vedeckého kongresu „Zoológia 2018"[Proceeding from the science congress "Zoology 2018"], TU, Zvolen. [In Slovak]

Gális M, Slobodník R, Chavko J, Deutschová L, Hapl E \& Šmídt J 2019: Energia v krajine - elektrické vedenia a ochrana prioritných druhov vtákov $\mathrm{v}$ územiach Natura 2000 [Energy in the land - power lines and conservation of priority bird species in Natura 2000 sites], 62. In: Bryja J, Horsák M, Horsáková V, Řehák Z \& Zukal J (eds), Zooologické dny. Sborník abstraktů z konference [Zoological Days. Proceedings abstracts from conference]. Institute of Vertebrate Biology Czech Academy of Sciences, Brno. [In Slovak]

Gális M \& Ševčík M 2019: Monitoring of effectiveness of bird diverters in preventing bird mortality from collisions with distribution power lines in Slovakia. Raptor Journal 13: 45-59. DOI: 10.2478/srj-20190005 .

Gombobaatar S, Damdin S, Shagdarsuren O, Potapov E 
\& Fox N 2004: Saker falcon (Falco cherrug milvipes Jerdon) mortality in Central Mongolia and population threats. Mongolian Journal of Biological Sciences 2: 13-21. DOI:10.22353/mjbs.2004.02.13

Guil F, Fernández-Olalla M, Moreno-Opo R, Mosqueda I, Gómez M, Aranda A, Arredondo Á, Guzman J, Oria J, Garcia L \& Margalida A 2011: Minimising mortality in endangered raptors due to power lines: The importance of spatial aggregation to optimize the application of mitigation measures. PloS One 6: e28212. DOI: 10.1371/journal.pone.0028212.

Guyonne F, Janss E \& Ferrer M 2001: Avian electrocution mortality in relation to pole design and adjacent habitat in Spain. Bird Conservation International 11: 3-12. DOI: 10.1017/ S0959270901001022

Haas D, Nipkow M, Fiedler G, Scheneider R, Haas W \& Schürenberg B 2005: Protecting birds from powerlines. Nature and Environment 140: 90.

Harness R \& Wilson KR 2001: Electric-utility structures associated with raptor electrocutions in rural areas. Wildlife Society Bulletin 29: 612-623.

Harness R, Gombobaatar S \& Yosef R 2008: Mongolia distribution power lines and raptor electrocutions. Institute of Electrical and Electronics Engineers 52:1-6.

Harness R, Juvvadi P \& Dwyer J 2013: Avian Electrocutions in Western Rajasthan, India. Journal of Raptor Research 47: 352-364. DOI: 10.3356/ JRR-13-00002.1.

Heredia B 1996: International action plan for the Imperial eagle (Aquila heliaca), 159-174. In: Heredia B, Rose L \& Painter M (eds), Globally threatened birds in Europe: action plans. Council of Europe, and BirdLife International, Strasbourg.

Horváth M, Demeter I, Fatér I, Firmánszky G, Kleszó A, Kovács A, Szitta T, Tóth I, Zalai T \& Bagyura J 2011: Population dynamics of the eastern imperial eagle (Aquila heliaca) in Hungary between 2001 and 2009. Acta Zoologica Bulgarica: 61-70.

Hunting K 2002: A roadmap for PIER research on avian collisions with power lines in California. California Energy Commission, PIER Energy-Related Environmental Research. Technical Report P500-02-071F.

Infante S, Neves J, Ministro J \& Brandão R 2005: Estudo sobre o Impacto das Linhas Eléctricas de Média e Alta Tensão na Avifauna em Portugal. Quercus Associação Nacional de Conservação da Natureza e SPEA Sociedade Portuguesa para o Estudo das Aves, Castelo Branco. [In Portugal with English summary]
Janss G \& Ferrer M 2001: Avian electrocution mortality in relation to pole design and adjacent habitat in Spain. Bird Conservation International 11: 3-12. DOI: $10.1017 /$ S0959270901001022

Jenkins A, Smallie J \& Diamond M 2010: Avian collisions with power lines: A global review of causes and mitigation with a South African perspective. Bird Conservation International 20: 263278. DOI: $10.1017 / \mathrm{S} 0959270910000122$.

Karaska D, Trnka A, Krištin A \& Ridzoň J 2015: Chránene vtáčie územia Slovenska [Special Protecting Areas of Slovakia]. Štátna ochrana prírody SR, Banská Bystrica. [In Slovak]

Karyakin IV, Nikolenko EG, Vazhov SV \& Bekmansurov RH 2009: Raptor electrocution in the Altai region: results of surveys in 2009, Russia. Raptor Conservation 16: 45-64.

Kelly A \& Kelly S 2009: Are mute swans with elevated blood lead levels more likely to collide with overhead power lines? Waterbirds 28: 331-334. DOI: 10.1675/1524-4695(2005)028[0331:AMSWEB]2.0. $\mathrm{CO} ; 2$

Koops FBJ 1994: Collision victims of high-tension lines in The Netherlands and effects of marking, 51-57. In: First technical sessions on power lines and the environment. Red Electrica de España, Madrid.

Kovács A, Williams NP \& Galbraith CA 2014: Saker falcon (Falco cherrug) global action plan (SakerGAP). CMS Raptors MOU Technical Publication No. 2. CMS Technical Series No. 31.

Lehman R, Savidge J, Kennedy P \& Harness R 2010: Raptor electrocution rates for a utility in the intermountain western United States. Journal of Wildlife Management 74: 459-470. DOI: 10.2193/2008-332

Loss SR, Will T \& Marra PP 2014: Refining estimates of bird collision and electrocution mortality at power lines in the United States. PLoS ONE 9(7): e101565. DOI: 10.1371 /journal.pone.0101565

Manville II AM 2005: Bird strikes and electrocutions at power lines, communication towers, and wind turbines: state of the art and state of the science next steps toward mitigation, 1051-1064. In: Ralph CJ \& Rich TD (eds), Bird Conservation Implementation and Integration in the Americas: Proceedings of the Third International Partners in Flight Conference. March 20-24, 2002; Asilomar, California, Volume 2 Gen. Tech. Rep. PSW-GTR191. S. Dept. of Agriculture, Forest Service, Albany, CA.

Martin GR \& Shaw JM 2010: Bird collisions with 
Gális M, Nad’o L, Hapl E, Šmídt J, Deutschová L \& Chavko J: Comprehensive analysis of bird mortality along power

distribution lines in Slovakia

power lines: failing to see the way ahead? Biological Conservation 143: 2695-2702. DOI: 10.1016/j.biocon.2010.07.014.

Martin GR 2011: Understanding bird collisions with man-made objects: A sensory ecology approach. Ibis 153: 239-254. DOI: 10.1111/j.1474-919X.2011. 01117.x.

Mathiasson S 1993: Mute swans, Cygnus olor, killed from collision with electrical wires, a study of two situations in Sweden. Environmental pollution 80: 239-246. DOI: 10.1016/0269-7491(93)90044-O.

Moleón M, Bautista J, Garrido JR, Martín-Jaramillo J, Ávila E \& Madero A 2007: Correcting power lines in dispersal areas of Bonelli's eagles: potential positive effects on the raptor community. Ardeola 54: 319-325.

Nagy S \& Demeter I 2006: Saker falcon: European single species action plan. Bern Convention: T-PVS/ Inf (2006) 2 Council of Europe, Strasbourg. Retrieved July 15, 2019, from https://rm.coe.int/ 1680746623.

Nemček V, Chavko J \& Deutschová L 2014: Movement of satellite-tracked juvenile saker falcons (Falco cherrug) in SW Slovakia. Slovak Raptor Journal 8: 97-103. DOI: 10.2478/srj-2014-0011.

Nemček V, Uhrin M, Chavko J, Deutschová L, Maderič B \& Noga M 2016: Habitat structure of temporary settlement areas of young saker falcon Falco cherrug females during movements in Europe. Acta Ornithologica 51: 93-103. DOI: 10.3161/ 00016454AO2016.51.1.008.

Neves J, Infante S, Ministro J \& Brandão R 2005: Impact of transmission lines on birds in Portugal. Sociedade Portuguesa para o Estudo das Aves and Quercus Associação Nacional de Conservação da Natureza, Castelo Branco.

Perrins CM \& Sears J 1991: Collisions with overhead wires as a cause of mortality in mute swans Cygnus olor. Wildfowl 42: 5-11.

Ponce C, Alonso JC, Argandona G, Garcia Fernandez A \& Carrasco M 2010: Carcass removal by scavengers and search accuracy affect bird mortality estimates at power lines. Animal Conservation 13: 603-612. DOI: $10.1111 / \mathrm{j} .1469-1795.2010 .00387 . x$

Prinsen HAM, Boere GC, Píres N \& Smallie JJ (eds) 2011: Review of the conflict between migratory birds and electricity power grids in the AfricanEurasian region. CMS Technical Series No. XX, AEWA, Bonn.

Prommer M, Bagyura J, Chavko J \& Uhrin M 2012:
Migratory movements of central and eastern European saker falcons (Falco cherrug) from juvenile dispersal to adulthood. Aquila 119: 111-134.

Prosser P, Nattras C \& Prosser C 2008: Rate of removal of bird carcasses in arable farmland by predators and scavengers. Ecotoxicology and Environmental Safety 71: 601-608. DOI: 10.1016/j.ecoenv. 2007.10.013.

R Core Team 2019R: A language and environment for statistical computing. R Foundation for Statistical Computing, Vienna, Austria. Retrieved June 21, 2019, from https://www.R-project.org/.

Roig J \& Navazo V 1997: A five-year Spanish research project on bird electrocutions and collisions with electric lines: 317-325. In: Williams JR, GoodrichMahoney JW, Wisniewski JR \& Wisniewski K (eds), The Sixth International Symposium on Environmental Concerns in Rights-of-Way Management. Elsevier, Oxford.

Rubolini D, Bassi E, Bogliani G, Galeotti P \& Garavaglia R 2001: Eagle owl Bubo bubo and power line interactions in the Italian Alps. Bird Conservation International 11: 319-324.

Samusenko I, Novitsky R \& Pakul P 2012: The problem of bird mortality on power lines in Belarus: Preliminary results of studies. Pernatye khishniki i ikh okhrana/Raptors Conservation 24: 118-131.

Savereno AJ, Savereno LA, Boettcher R \& Haig SM 1996: Avian behavior and mortality at power lines in coastal South Carolina. Wildlife Society Bulletin, 24: 636-648.

Shobrak M 2012: Electrocution and collision of birds with power lines in Saudi Arabia. Zoology of Middle East 57: 45-52. DOI: 10.1080/09397140.2012. 1064896.

Shaw JM, Jenkins AR, Smallie JJ \& Ryan PG 2010: Modelling powerline collision risk for the blue crane Anthropoides paradiseus in South Africa. Ibis 152: 590-599. DOI: 10.1111/j.1474-919X.2010.01039.x.

Scherer R 2018: PropCIs: Various confidence interval methods for proportions. $\mathrm{R}$ package version $0.3-0$. Retrieved June 21, 2019, from https://github.com/ shearer/PropCIs.

Sporer MK, Dwyer JF, Gerber BD, Harness RE \& Pandey AK 2013: Marking power lines to reduce avian collisions near the Audubon National Wildlife Refuge, North Dakota. Wildlife Society Bulletin 37: 796-804. DOI: 10.1002/wsb.329.

Spray CJ 1991: Population dynamics of mute swans Cygnus olor in the Outer Hebrides, Scotland. In: 
Sears J \& Bacon PJ (eds): Proc. Third IWRB International Swan Symposium, Oxford, Wildfowl Supplement No. 1: 143.

Stehn T \& Wassenich T 2008: Whooping crane collisions with power lines: an issue paper, 25-36. In: Folk MJ \& Nesbitt SA (eds), Proceedings of the Tenth North American Crane Workshop, Feb. 7-10, 2006, Zacatecas, Mexico. North American Crane Working Group, Grand Island, Nebraska.

Stoychev S, Demerdzhiev D, Spasov S, Dobrev D \& Meyburg BU 2014: Survival rate and mortality of juvenile and immature eastern imperial eagles (Aquila heliaca) from Bulgaria studied by satellite telemetry. Slovak Raptor Journal 8: 53-60. DOI: 10.2478/srj-2014-0008.

Šmídt J, Hapl E \& Gális M 2019: Methodology of risk assessment for electricity distribution lines in Slovakia with regard to potential bird mortality due to collisions with power lines. Raptor Journal 13: 6173. DOI: $10.2478 /$ srj-2019-0008.

Škorpíková V, Hlaváč V \& Křápek M 2019: Bird mortality on medium-voltage power lines in the Czech Republic. Raptor Journal 13: 27-44. DOI: 10.2478/ srj-2019-0007.
Venables WN \& Ripley BD 2002: Modern applied statistics with S. Fourth Edition. Springer, New York.

Veselovský T, Chavko J \& Guziová Z 2018: Telemetria orlov královských (Aquila heliaca) na Slovensku. [Telemetry of imperial eagles in Slovakia], 231-232. In: Bryja J \& Solský M (eds), Zoologické dny. Sborník abstraktů z konference [Zoological Days. Proceedings abstracts from conference]. Institute of Vertebrate Biology Czech Academy of Sciences, Brno. [In Slovak]

Ward JP \& Anderson SH 1992: Sandhill crane collisions with power lines in southcentral Nebraska, 189-196. In: Wood DA (ed.), Proceedings 1988 North American Crane Workshop, Feb. 22-24. Lake Wales, Florida. State of Florida Game and Fresh Water Fish Commission Nongame Wildlife Program Technical Report \#12, Tallahassee, FL.

Wright G, Smith TJ, Murphy R, Runge JT \& Harms RR 2008: Mortality of cranes (Gruidae) associated with powerlines over a major roost on the Platte River, Nebraska. Prairie Naturalist 41: 116-120. 